\title{
Carrots \& Sticks: How VCs Induce Entrepreneurial Teams to Sell Startups
}

\section{Citation}

Brian Broughman \& Jesse M. Fried, Carrots \& Sticks: How VCs Induce Entrepreneurial Teams to Sell Startups, 98 Cornell L. Rev. 1319 (2013).

\section{Published Version}

http://scholarship.law.cornell.edu/cgi/viewcontent.cgi?article=3281\&context=clr

\section{Permanent link}

http://nrs.harvard.edu/urn-3:HUL.InstRepos:30006869

\section{Terms of Use}

This article was downloaded from Harvard University's DASH repository, and is made available under the terms and conditions applicable to Open Access Policy Articles, as set forth at http:// nrs.harvard.edu/urn-3:HUL.InstRepos:dash.current.terms-of-use\#OAP

\section{Share Your Story}

The Harvard community has made this article openly available.

Please share how this access benefits you. Submit a story.

Accessibility 
ISSN 1936-5349 (print)

ISSN 1936-5357 (online)

\title{
HARVARD
}

JOHN M. OLIN CENTER FOR LAW, ECONOMICS, AND BUSINESS

\author{
CARROTS \& STICKS: \\ HOW VCS INDUCE ENTREPRENEURIAL \\ TEAMS TO SELL STARTUPS
}

\author{
Brian Broughman \\ Jesse M. Fried
}

Discussion Paper No. 742

$03 / 2013$

Harvard Law School

Cambridge, MA 02138

This paper can be downloaded without charge from:

The Harvard John M. Olin Discussion Paper Series:

http://www.law.harvard.edu/programs/olin_center/

This paper is also a discussion paper of the

John M. Olin Center’s Program on Corporate Governance. 


\title{
CARROTS \& STICKS: HOW VCs INDUCE ENTREPRENEURIAL TEAMS TO SELL STARTUPS

\author{
Brian Broughman $^{*}$ and Jesse M. Fried ${ }^{* *}$
}

FEBRUARY 19, 2013

\begin{abstract}
$\underline{\text { Abstract }}$
Venture capitalists (VCs) usually exit their investments in a startup via a trade sale. But the entrepreneurial team - the startup's founder, other executives, and common shareholders - may resist a trade sale. Such resistance is likely to be particularly intense when the sale price is low relative to VCs' liquidation preferences. Using a hand-collected dataset of Silicon Valley firms, we investigate how VCs overcome such resistance. We find, in our sample, that VCs give bribes (carrots) to the entrepreneurial team in $45 \%$ of trade sales; in these sales, carrots total an average of $9 \%$ of deal value. The overt use of coercive tools (sticks) occurs, but only rarely. Our study sheds light on important but underexplored aspects of corporate governance in VC-backed startups and the venture capital ecosystem.

*Associate Professor of Law, Indiana University

** Professor of Law, Harvard Law School. For helpful conversations and comments, we are grateful to Abe Cable, Herb Fockler, Darian Ibrahim, Jason Mendelson, Edwin Miller, Usha Rodrigues, Ezra Roizen, Josh Wolfe, participants at the Cornell Symposium on Law, Innovation, and Entrepreneurship and, especially, Mike Kendall and Sarah Reed. We would also like to thank Meg Burton, Albert Chang, Cynthia Chi, Edward Dumoulin, Jennifer Su, Bruce Sun, and Fennie Wang for valuable research assistance. VentureReporter.net provided access to their database of mergers and acquisitions. This project was generously supported by a grant from the Kauffman Foundation through the Lester Center for Entrepreneurship and Innovation at UC Berkeley while the two authors were affiliated with UC Berkeley, as well as by the Harvard Program on Corporate Governance and the John M. Olin Center for Law, Economics, and Business at Harvard Law School. Most importantly, we thank the many entrepreneurs who agreed to provide data for our research.
\end{abstract}


Version 2/19/13

\section{Carrots $\mathcal{E}$ Sticks}

\section{Carrots and Sticks: How VCs Induce Entrepreneurial Teams to Sell Startups}

Table of Contents

I. INTRODUCTION 1

II. VCs' CASH-FLOW AND CONTROL RIGHTS 6

A. VCs' Cash-Flow Rights 6

B. VCs' Exit-Facilitating Control Rights 7

1. Board Seats 7

2. Shareholder Rights 9

III. POTENTIAL ENTREPRENEURIAL-TEAM 10

RESISTANCE TO TRADE SALES

A. Resistance by the Founder and Executives 10

1. Incentive 10

2. Ability 11

B. Opposition by Common Shareholders $\quad 11$

1. Incentive 11

2. Ability 12

IV. VCs' Potential CARRots AND STICKS 13

A. Founders and Executives 14

1. Carrots 14

2. Sticks 14

B. Common Shareholders 15

1. Carrot: Carve-out to Common 15

2. Sticks 15

C. Carrots vs. Sticks 17

V. RESEARCH SAMPLE 18

A. Sample Population 18

1. Data Gathering 18

2. Selection Issues 19

B. Sample Description 20

C. VCs' Ex Ante Cash and Control Rights 20

1. VCs' Cash-Flow Rights 20

2. Power of the Entrepreneurial Team 21

3. Founders' Position in the Firm 23

VI. ACtUAL CARROTS AND STICKS IN THE SALE OF 23 VC-BACKED STARTUPS

A. Carrots 24

1. Common Carve-outs 24

2. (Non-retention) Management Bonuses 25

3. Cost of Carrots 26

B. Sticks 26

1. Termination of CEO 27

2. Blacklisting 27

3. Cross-voting 28

4. Vote-buying 28

VII. CONCLUSION 29 


\section{Introduction}

Venture capitalists (VCs) play a significant role in the financing of high-risk, technology-based business ventures. Many of America's best-known public companies began as VC-backed firms: Amazon.com, Apple, FedEx, Intel, Microsoft, and Starbucks, to name a few. Not surprisingly, venture capital is considered to be an important contributor to economic growth in the United States and elsewhere. ${ }^{1}$

The steps in the venture capital cycle are by now familiar. ${ }^{2}$ A VC firm creates and raises capital for a limited-life fund. ${ }^{3}$ The VCs select portfolio companies for the fund, investing in these companies over a number of rounds of financing. ${ }^{4}$ Along the way, the VCs advise and monitor the portfolio companies, sometimes replacing their founders. ${ }^{5}$ Before the end of the fund's life, VCs "exit" their investments in the portfolio companies and return capital to the fund's investors. ${ }^{6}$ The returned capital can then be recycled into another VC fund.

VC exits usually take one of three forms: an initial public offering (IPO) of the portfolio company's shares, followed by the sale of the VC's shares into the public market; a "trade sale" of the company to another firm; or dissolution and liquidation of the company. ${ }^{7}$ Of these three types of exits, IPOs have received the most scrutiny. ${ }^{8}$ This

\footnotetext{
${ }^{1}$ See, e.g., Josh Lerner, Boom and Bust in the Venture Capital Industry and the Impact on Innovation, 87 FED. RES. BANK OF ATLANTA ECON. REV. 25 (2002) (concluding that venture capital is "an important contributor to technological innovation and economic prosperity”).

2 For an overview, see Paul Gompers \& Josh Lerner, The Venture Capital Cycle (2d ed. 2004).

${ }^{3}$ See, e.g., Michael D. Klausner \& Kate Litvak, What Economists Have Taught Us About Venture Capital Contracting, in BRIDGING THE ENTREPRENEURIAL FINANCING GAP: LiNKING GOVERNANCE WITH REGULATORY POLICY (Michael Whincop ed., 2001) (describing and analyzing terms of limited partnership agreements with investors); William A. Sahlman, The Structure and Governance of Venture-Capital Organizations, 27 J. FIN. ECON. 473, 473 (1990) (describing and analyzing relationship between investors and VCs).

${ }^{4}$ See, e.g., Paul A. Gompers, Optimal Investment, Monitoring, and the Staging of Venture Capital, 50 J. FIN. 1461, 1461 (1995) (analyzing structure of VC investments and attributing staged financing to information asymmetries and agency costs); Brian Broughman and Jesse M. Fried, Do VCs Use Inside Rounds to Dilute Founders? Some Evidence from Silicon Valley, 18 J. CoRP. FIN. 1104, 1104-20 (2012) (finding that VCs do not appear to use inside rounds to dilute founders).

${ }^{5}$ George W. Fenn, Nellie Liang \& Stephen Prowse, The Economics of the Private Equity Market, BD. OF GovernORS OF THE FED. RESERVE SYS., Staff Studies Series No. 168, 29 (1995) (studying private equity markets and describing VCs' investing activities including selecting, structuring, monitoring, and exiting).

${ }^{6}$ Id.

${ }^{7}$ Other forms of VC exit include the VC's sale of its interests in the startup to one or more private equity firms, and one VC's sale of its interest to another VC (a “secondary”). See Darian M. Ibrahim, The New Exit in Venture Capital, 65 VAND. L. REV. 1, 16-17, 19-20 (2012) (discussing how VCs are increasingly becoming sellers on the secondary market, and how buyers on the secondary market include VCs and private equity funds). These forms of exit merely replace some or all of the firm's existing VCs with new investors, without substantially altering the relationship between the startup's investors and its entrepreneurial team. Thus, they do not create the types of conflicts explored in this paper - those that can
} 


\section{Carrots $\mathcal{E}$ Sticks}

attention is not surprising. IPO exits tend to involve the largest and most visible VCbacked firms. And, perhaps just as importantly, the IPO process triggers public-disclosure requirements under the securities laws, making data on IPO exits easily accessible to researchers.

But trade sales are actually much more common than IPOs and, in aggregate, are likely to be almost as financially important to VCs. Indeed, in certain industries (such as medical devices) and in certain periods (such as the last decade, when the IPO market has been tepid), trade sales, compared to IPOs, are likely to be more important to VCs. ${ }^{9}$ Unlike IPOs, however, trade sales do not trigger the intense public-disclosure requirements of the securities laws; they take place in the shadows. ${ }^{10}$ Thus, although trade sales are important to the venture capital cycle, relatively little is known about them.

The purpose of this paper is to shine a light on how VCs arrange to sell startups in trade sales. In particular, we seek to investigate how VCs induce the "entrepreneurial team" - the founder, other executives, and common shareholders - to go along with a trade sale that they might have an incentive to resist.

We begin by describing the standard cash-flow and control rights that VCs receive when investing in startups. VCs almost always invest through convertible preferred stock. In a trade-sale exit, VCs choose between retaining their preferred shares (and capturing most or all of the proceeds through their liquidation preferences), or converting into common shares. In an IPO, VCs (as a practical matter) must convert to

arise in sales of the portfolio company to another operating company. Less commonly, a VC may exit by having the portfolio company redeem the VC's shares.

${ }^{8}$ See, e.g., Bernard S. Black \& Ronald J. Gilson, Venture Capital and the Structure of Capital Markets: Banks Versus Stock Markets, 47 J. FIN. ECON. 243, 243 (1998) (analyzing VCs' exits through IPOs and relation between stock market and the VC market); Malcolm Baker and Paul A. Gompers, The Determinants of Board Structure at the Initial Public Offering, 46 J.L. \& Econ. 569, 569 (2003) (finding that VC-backed IPO firms have more independent outside directors).

${ }^{9}$ See, e.g., News Release, Thomson Reuters \& National Venture Capital Association, Venture-Backed Exits Enjoyed Higher Average Values on Lower Total Volumes in 20122 (Jan. 2, 2013), available at http://www.nvca.org/index.php?option=com_docman\&task=doc_download\&gid=929\&Itemid=317 (reporting that M\&A deals have exceeded IPOs in terms of both deal number and dollar amount yearly between 2007 and 2012); Nils Behnke \& Norbert Hültenschmidt, New Path to Profits in Biotech: Taking the Acquisition Exit, 13 JoURNAL OF COMMERCIAL BIOTECHNOLOGY 78, 79-80 (2007) (reporting that VCs in medical device companies traditionally exited via trade sale and that VCs in biotech companies are increasingly choosing trade sales over IPOs).

${ }^{10}$ If the acquirer is publicly-held and the acquisition is deemed a "material" agreement then the acquirer must disclose in Form 8-K "a brief description of the terms and conditions of the agreement ... that are material to the company.” See SEC Final Rule Release 34-49424, Additional Form 8-K Disclosure Requirements and Acceleration of Filing Date, available at http://www.sec.gov/rules/final/338400.htm\#seciic. Form 8-K disclosure only applies, however, to material transactions and the acquirer does not need to file the actual merger agreement or provide other details about the target firm. See id. 


\section{Carrots $\mathcal{E}$ Sticks}

common stock. ${ }^{11}$ VCs also seek board seats and shareholder-voting rights, in part to make it easier for them to exit and realize their cash-flow rights.

We then explain why founders, executives, and common shareholders are more likely to oppose a trade-sale exit than an IPO exit. In an IPO, the founder (if still the CEO) can continue running the firm and will face less direct oversight as shareholdings become more diffuse. ${ }^{12}$ Other executives can typically keep their jobs, also with less shareholder oversight than before. And the original common shareholders of firms conducting IPOs generally do well; VCs would not push for an IPO exit unless the common shares (to which the VCs must convert in an IPO) have considerable value.

By contrast, in a trade sale, the founder (if still the CEO) and other executives may lose their jobs or find themselves subject to more direct oversight as shareholdings become concentrated in the hands of a single shareholder (the acquirer). In other words, they become "mere" employees. And, because VCs in trade sales often exit as preferred shareholders with liquidation preferences that must be paid in full before common shareholders receive any payout, common shareholders may receive little (if any) payout. ${ }^{13}$ At the same time, the sale eliminates any "option value" (upside potential) of the common stock held by the founder, other executives, and employees. ${ }^{14}$ For all these reasons, VCs pushing for a trade sale may face resistance from the entrepreneurial team, particularly when common shareholders receive very little.

Two points are worth emphasizing here. First, an entrepreneurial team resisting a trade sale may not necessarily believe that, if the startup remains independent, the startup has a reasonable chance of going public. Rather, they may resist a trade sale today because they believe that, if the startup remains independent, there is a good chance that it can exit in the future via a more attractive trade sale - one that provides significantly better employment opportunities for the entrepreneurial team and more value for common shareholders. ${ }^{15}$

\footnotetext{
${ }^{11}$ In an IPO, VCs typically convert their preferred stock into common, either because it is contractually required, or because preferred shares almost never survive an IPO given market resistance. Thus, VCs are likely to push for an IPO only when the common stock they would receive upon converting their shares is worth more than the preferred stock's liquidation preferences (plus, where relevant, the preferred stock's participation rights).

12 Black \& Gilson, supra note 8, at 260-61 (noting that an IPO returns effective control of the firm to the $\mathrm{CEO}$ /founder).

${ }^{13}$ Of course, if the trade sale is at a high price relative to aggregate liquidation preferences, common shareholders may well receive a large payout even if the preferred shareholders do not convert to common.

${ }^{14}$ For a discussion of the “option value” of common stock in VC-backed firms, see infra Part III.B.1.

${ }^{15}$ VCs, on the other hand, may want to sell the firm now and capture most of the sale price through their liquidation preferences. Should the firm remain independent, it might end up being sold for a much lower price than is currently being offered. Thus, the VCs bear the downside risk associated with keeping the startup independent. See Jesse M. Fried \& Mira Ganor, Agency Costs of Venture Capitalist Control in Startups, 81 N.Y.U. L. REV. 967, 978-79 (2006). In addition, or alternatively, VCs may wish to sell the firm
} 


\section{Carrots $\mathcal{E}$ Sticks}

Second, there may well be situations where the entrepreneurial team favors a trade sale opposed by the VCs. For example, the entrepreneurial team might wish to accept an offer that is lucrative for them personally (given the short amount of time they have spent on the venture) but that provides only a very modest return to the VCs. ${ }^{16}$ Thus, we do not claim that the entrepreneurial team will always oppose a trade sale. Rather, our claim is that there are likely to be many scenarios where VCs will favor a trade sale opposed by the entrepreneurial team.

After describing the entrepreneurial team's potential incentive to resist a trade sale, we discuss the various strategies they might use to impede the sale. The executives and common shareholders can impede a trade sale through their influence over the board, which must approve the transaction. The common shareholders can try to block the sale by exercising their voting rights or by threatening litigation. And the executives can refuse to cooperate in the sale process (or, if the acquisition requires their continued participation in the enterprise, refuse to commit to such participation).

Next, we identify the various bribes (carrots) and coercive tools (sticks) that VCs can use to induce a reluctant entrepreneurial team to support, or at least not impede, a trade sale. For the founder and other executives, the VCs can offer bonuses for a successful sale (carrot). The VCs can also threaten termination or blacklisting if the executives do not cooperate (sticks).

For common shareholders, VCs can offer to share part of the VCs' cash-flow rights with the common shareholders through a "carve-out to common" (carrot). They can also use vote buying, or other transactions that dilute common shareholder voting rights, to undermine common shareholders' ability to block a transaction via their voting rights (sticks).

To investigate the use of carrots and sticks in trade sales, we use a hand-collected database of 50 VC-backed Silicon Valley firms sold to acquirers in 2003 and 2004. The firms are primarily in the biotech, telecommunications, software, and internet sectors. The average sale price is $\$ 55$ million, but there is considerable variance in outcomes. A number of sales are essentially liquidations, while other sales are for well over $\$ 100$ million; one firm is sold for over $\$ 500$ million. For each firm, we collect data on the carrots and sticks used in connection with the sale. ${ }^{17}$

now to show prospective investors for their next fund that the VCs can successfully exit their investments, or because the fund in which the portfolio company is held is coming to the end of its life.

${ }^{16}$ See, e.g., Darian Ibrahim, The New Exit in Venture Capital, 65 VAND. L. REV. 1, 28-29 (2012).

17 This paper builds on earlier work using portions of the same dataset. See Brian Broughman \& Jesse M. Fried, Renegotiation of Cash Flow Rights in the Sale of VC-Backed Firms, 95 J. FIN. ECON. 384, 384-399 (2010) (showing that common shareholders' ability to extract carve-outs from VCs depends on the allocation of control rights within the firm as between common shareholders and preferred shareholders). In this paper, we use additional information gathered in our study to provide a more complete picture of VCs' efforts to induce entrepreneurial teams to sell firms by describing (1) the carrots given to both common shareholders and executives; and (2) VCs' use of various sticks, including blacklisting threats, vote buying, and vote dilution. 


\section{Carrots $\mathcal{E}$ Sticks}

We find, in our sample, a heavy reliance on carrots. To induce executives to cooperate in selling their firms, VCs frequently offer sale bonuses. In 16 of the 50 firms, VCs paid an average sale bonus of $\$ 1.63$ million. In 11 of the 50 firms, VCs gave common shareholders as a class an average of $\$ 3.7$ million extra. In $45 \%$ of the firms, VCs gave at least one type of carrot, with these carrots amounting to $9 \%$ of deal value on average for such firms. Across all 50 firms in our sample, an average of $4.3 \%$ of deal value (2.4\% on a dollar-weighted basis) was used to fund these two types of carrots: sale bonuses and carve-outs to common. ${ }^{18}$

We also find some use of sticks, such as threats to blacklist founders who refuse to cooperate and attempts to undermine common shareholders' voting rights. But the overt use of these sticks is relatively infrequent. And although $60 \%$ of the founders in our firms were replaced before the sale, we find no evidence that VCs fired or threatened to fire founders to ease the sales of firms.

Our study makes three important contributions to the literature. First, it sheds light on an important but underexplored aspect of corporate governance in private VC-backed firms. In particular, it highlights the potentially divergent interests of different players in VC-backed firms around trade-sale exits, and shows that VCs frequently must overcome potential opposition to these sales.

Second, our study provides additional evidence that managers of a target firm can extract value by holding up a sale of the firm. Researchers have reported on the use of side payments to executives in the sale of publicly traded firms. ${ }^{19}$ We show that such "bribes" are used not only in public firms with dispersed ownership but also in closelyheld private firms.

Third, our study provides some evidence on whether venture capitalists are constrained from abusing their power in startups. The relatively infrequent use of sticks in our sample provides support for the view that reputational or other non-legal considerations substantially constrain (but do not completely prevent) sharp-elbowed behavior by venture capitalists in Silicon Valley. ${ }^{20}$

The remainder of the paper is structured as follows. Part II describes the typical structure of VC cash-flow and exit-facilitating control rights in startup firms. Part III explains why founders, other executives, and common shareholders may wish to impede a trade sale, as well as the means they have to do so. Part IV describes the carrots and

\footnotetext{
18 The use of carrots is greater in the 42 firms in our sample where the VC investors did not convert to common stock, and thus where the conflict between the entrepreneurial team and VCs was likely to be the greatest. In this subsample of 42 firms we find that $5.0 \%$ of deal value (3.1\% on a dollar-weighted basis) was used to fund carrots.

19 See, e.g., Hartzell, Ofek \& Yermack, What's In It for Me? CEOs Whose Firms Are Acquired, 17 REV. FIN. STUD, 37, 37-61 (2004) (finding, in a sample of acquired firms, that target managers frequently receive non-retention bonuses in connection with the sale of the firm and that such payments average \$1.2 million).

${ }^{20}$ See, e.g., Black \& Gilson, supra note 8, at 262-83 (1998) (suggesting that reputational considerations constrain misbehavior by venture capitalists in Silicon Valley).
} 
Carrots $\mathcal{E}$ Sticks

sticks that VCs may use to overcome such resistance. Part V presents our dataset. Part VI describes carrots and sticks actually used by VCs in our sample. Part VII concludes.

\section{VCs' Cash-Flow and Control Rights}

\section{A. VCs' Cash-Flow Rights}

In the United States, VC-backed startups almost always issue two classes of stock: common and convertible preferred. The founders and employees hold the common stock. The convertible preferred stock is held by VCs, who invest in startups almost exclusively through this type of security. ${ }^{21}$ Most venture-backed startups issue a new series of preferred stock for each round of financing. ${ }^{22}$

Like most preferred stock, VCs' preferred shares carry a liquidation preference and are convertible into common. ${ }^{23}$ If VCs retain their preferred stock, and preserve their liquidation preferences, those preferences must be satisfied before common shareholders receive any payment. In this scenario, VCs' cash flow rights are debt-like. ${ }^{24}$ If the VCs convert their preferred shares to common, giving up their liquidation preferences, the VCs have the same cash flow rights as common stockholders. ${ }^{25}$ Thus, convertible preferred stock combines downside protection with upside potential.

\footnotetext{
${ }^{21}$ See Steven N. Kaplan \& Per Stromberg, Financial Contracting Theory Meets the Real World: An Empirical Analysis Of Venture Capital Contracts, 70 REV. ECON. STUD. 281, 313 (2003). VCs' use of preferred stock may have desirable screening, incentive, and tax-reducing effects. See, e.g., Fried \& Ganor, supra note $\mathrm{x}$, at 983-86.

${ }^{22}$ While some of the rights of the preferred stockholders may be class rights, each series of preferred stock is assigned its own exclusive rights and preferences, including liquidation preferences that may be senior or junior to those of other series. This, in turn, may give rise to conflicts within the preferred class over exits and other transactions. Indeed, in certain situations, the interests of the most junior preferred may be closer to those of common than to those of the most senior preferred. In this project, we implicitly assume that all of a firm's VCs share the same interests (vis-à-vis common shareholders, the founders, and other executives) around the potential sale of the firm.
}

${ }^{23}$ See Kaplan \& Stromberg, supra note $\mathrm{x}$, at 285, Table 1 Panel G (finding that almost all VC financings in the U.S. involve securities senior to common).

${ }^{24}$ Unlike the liquidation preferences of most public-company preferred stock, VCs' liquidation preferences can easily exceed the original purchase price of the stock: the liquidation preference of VC preferred stock sometimes confers the right to be paid a multiple of the purchase price before common shareholders may receive any payment. See, e.g., Vyvyan Tenorio, VCs Reconsider Tough Terms for Entrepreneurs, THE DAILY DEAL, Jan. 28, 2002 (reporting deal with liquidation preferences of 12 times original purchase price). When the preferred shareholders are entitled to cumulative dividends, the liquidation preferences are even larger because they include, in addition to the multiple, any unpaid dividends (even if not declared). See Michael Woronoff \& Jonathan Rosen, Effective vs. Nominal Valuations in Venture Capital Investing, 2 N.Y.U. J.L. \& Bus 199, 218 (2005).

${ }^{25}$ VCs' convertible preferred stock may have "participation rights" that entitle holders not only to a liquidation preference, but also to share (with common shareholders, on a pro-rata basis) in any additional value available for distribution to shareholders, usually up to a specified amount (say, three times the original investment amount). Thus, the VCs will convert their preferred shares into common stock only if 
In a trade sale, VCs will choose whether to exit as preferred shareholders and reap the benefits of their liquidation preferences or to exit as common shareholders. If VCs exit via an IPO, underwriters will typically insist that the VCs convert to common shares and give up their liquidation preferences and other rights. Thus, the firm's charter will, with respect to the holders of each series of preferred stock, generally either (a) require the holders of that series to convert to common or (b) allow a majority of the holders of that series to forcibly convert all holders of that series to common stock, preventing holdouts. $^{26}$ One way or the other, VCs will typically exit via the IPO as common shareholders.

\section{B. VCs’ Exit-Facilitating Control Rights}

To exit their investment, VCs must arrange an IPO, trade sale, or dissolution of the firm. Below, we describe the two types of control rights most relevant to facilitating an exit: (1) the right to board seats and (2) shareholder voting rights. ${ }^{27}$

\section{Board Seats}

The board is responsible for managing the day-to-day business and affairs of the company. ${ }^{28}$ Critically, the board is also the only corporate body that can initiate fundamental transactions, such as mergers, IPOs, or dissolutions. ${ }^{29}$ Because these transactions are almost always necessary for $\mathrm{VC}$ exit, we will call them "VC exit transactions." VC exit transactions (including trade sales) thus cannot go forward without board approval. But, as we will see, board approval alone is not sufficient. Shareholder approval is also necessary.

the amount they would receive as common stockholders exceeds the sum of their liquidation preference and the value of their participation rights. For ease of exposition, our discussion of VCs' cash-flow rights assumes that VCs' preferred stock is non-participating.

${ }^{26}$ See Thomas Hellmann, IPOs, Acquisitions, and the Use of Convertible Securities in Venture Capital, 81 J. FIN. ECON. 649, 650 (2006) (discussing the requirement of automatic conversion in the event of an IPO). For an example of a mandatory conversion provision see Section B.5 of the model "Certificate of Incorporation” provided by the National Venture Capital Association (NVCA), at 29-32, available at http://www.nvca.org/index.php?option=com_content\&view=article\&id=108\&Itemid=136.

${ }^{27}$ VCs also negotiate for numerous protective provisions that enable them to block a variety of corporate actions. See Fried \& Ganor, supra note $\mathrm{x}$, at 987. By tightly constraining the firm, these provisions give significant leverage to VCs and make it harder for founders and other common shareholders to resist demands that the firm be sold. Staged financing - the ability to withhold needed cash - also gives VCs substantial influence over corporate decision-making and increases their ability to sell the firm. Id.

${ }^{28}$ See, e.g., 8 Del. CODE ANN. § 141(a) (2001); CAL. CoRP. CODE § 300(a) (West 1990).

${ }^{29}$ Shareholders, on the other hand, usually cannot initiate fundamental transactions even when their approval is required to effectuate the transactions. See, e.g., Robert B. Thompson \& D. Gordon Smith, Toward a New Theory of the Shareholder Role: "Sacred Space" in Corporate Takeovers, 80 TEX. L. REV. 261, 301-03 (2001) (noting reactive nature of shareholder voting to board actions). 


\section{Carrots $\mathcal{E}$ Sticks}

The board, in turn, is elected — and can be replaced - by shareholders. ${ }^{30}$ In the typical public company, default statutory voting rules give each share one vote for each open board seat. By contrast, in a VC-backed firm, the parties typically negotiate a voting agreement that overrides default statutory voting rules. ${ }^{31}$ The agreement specifies the allocation of board seats among: (1) representatives of common shareholders; (2) representatives of VC investors; and (3) so-called "independent directors," typically industry experts or other outsiders with valuable experience and connections who are mutually appointed by the common shareholders and the VCs. ${ }^{32}$

Because board approval is necessary for VC exits, VCs negotiate aggressively for board seats when investing in startups. ${ }^{33}$ While data on board composition in private VCbacked firms are scarce, two persistent patterns emerge from various small-scale studies of VC contracting documents and VC-backed firms. First, VC board representation tends to increase with new financing rounds, especially outside rounds that bring in new VCs. ${ }^{34}$ Second, in a plurality of firms, neither common shareholders nor VC-appointed directors ever achieve outright control; the swing vote is in the hands of an independent director. ${ }^{35}$ Keeping the swing vote in the hands of an independent director makes it more difficult for either the common shareholders or the preferred shareholders to act opportunistically with respect to the other class of shareholders. ${ }^{36}$ But, as one of us has argued in other

${ }^{30}$ DeL. CoDE ANN. tit. 8, § 141(k)(2001).

${ }^{31}$ William W. Bratton, Venture Capital on the Downside: Preferred Stock and Corporate Control, 100 MicH. L. REV. 891, 899 (2002) (describing how venture capital transactions provide tailored voting arrangements for director elections).

${ }^{32}$ Kaplan \& Strömberg, supra note $\mathrm{x}$, at 287-89.

${ }^{33}$ VC board control serves other important purposes besides facilitating exit. It allows the VCs to monitor the operations of the firm, control entrepreneur opportunism, replace the entrepreneur with a professional manager should the founder not prove up to the task, and prevent the board from taking actions that benefit common shareholders at the expense of the preferred. See Fried \& Ganor, supra note x, at 989-993.

${ }^{34}$ D. Gordon Smith, The Exit Structure of Venture Capital, 53 UCLA L. REv. 315, 324 (2005) (studying exit provisions in VC contracting and finding increase in VCs' control over exit with the stage of investment).

${ }^{35}$ Cf. Steven N. Kaplan, Berk A. Sensoy \& Per Strömberg, Should Investors Bet on the Jockey or the Horse? Evidence from the Evolution of Firms from Early Business Plans to Public Companies 64 J. Fin. 75 (2009) (reporting that, by time of IPO, median VC directorship is 3, median management directorship is 2, and median outside directorship is 2). Kaplan \& Strömberg, supra note x, at 287 (finding, in a survey of 118 startups, that in 60\%, neither VCs nor common shareholders had control).

${ }^{36}$ See generally Brian J. Broughman, The Role of Independent Directors in Startup Firms, 2010 UTAH L. REV. 461 (showing that independent directors as tie-breakers can limit opportunistic conduct that may occur if entrepreneurs or investors were to control the board); Brian Broughman, Independent Directors and Shared Board Control in Venture Finance (April 6, 2012), R. L. \& ECON. (forthcoming) (providing a formal model of decision-making under shared board control with an independent director holding the tiebreaking seat). 


\section{Carrots $\mathcal{E}$ Sticks}

work, these studies (and the outwardly neutral appearance of independent directors) may understate the extent of de facto VC control over startup boards. ${ }^{37}$

\section{Shareholder Rights}

As noted above, for VCs seeking an exit transaction, board approval is not sufficient. Shareholder approval is also necessary.

As a matter of corporate law, some shareholder approval is always required. The nature of that approval will depend on the corporate law of the state in which the firm is domiciled as well as the firm's charter and other organizational documents. In some states, such as Delaware, the default arrangement is that a majority of preferred and common shares (voting together) must approve exit transactions. ${ }^{38}$ But alternative arrangements, including provisions giving particular series of preferred stock veto rights, are common. ${ }^{39}$ In other states, including California, a majority of each class of shares (including common stock) must approve exit transactions. ${ }^{40}$

As a matter of business practice, the buyer in a trade sale may also insist on shareholder approvals not required by corporate law or the firm's organizational documents. For example, a buyer might be concerned about appraisal rights. Under corporate law, dissenting shareholders in a merger (those voting against the transaction) can exercise appraisal rights and have a court determine the "fair value" of their shares; the buyer is then forced to pay fair value to these dissenters. ${ }^{41}$ If the court's determination of fair value is much higher than the amount paid per share in the transaction, the cost of acquiring the target could rise substantially. To minimize potential appraisal claims, an acquirer may insist that a super-majority of shareholders approve the transaction. ${ }^{42}$ The bottom line is that corporate law may provide only a floor for shareholder-approval requirements.

\footnotetext{
${ }^{37}$ See Fried \& Ganor, supra note x, at 988-89 (noting that (1) at least one director designated as a representative of the common shareholders will be the CEO, and if the CEO is not the founder but an executive hired by the VCs, he or she may feel some loyalty to the VCs rather than to common shareholders generally, and (2) so-called “independent directors” may not be truly independent of the VCs, even if nominally approved by both common shareholders and VCs, if they are drawn from the VCs' professional network and expect to interact with them in the future).

${ }^{38}$ See, e.g., DEL. CODE ANN. tit. 8, § 251 (2010 (requiring, for a merger, approval by holders of majority of outstanding stock).

${ }^{39}$ See Fried \& Ganor, supra note $\mathrm{x}$, at $970-71$.

${ }^{40}$ See, e.g., CAL. CORP. CODE $§ 1201$ (a) (2012) (requiring, for a corporate reorganization, approval by a majority of each class of outstanding shares).

${ }^{41}$ See, e.g., Del. CODE ANN. tit. 8,. § 262 (2010); CAL. CORP. CODE $\S 1312$ (2012).

${ }^{42}$ Historically, another reason for seeking a high percentage of target shareholder votes was to obtain favorable accounting treatment for the transaction. See, e.g., Orban v. Field, NO. 12820, 1997 Del. Ch. LEXIS 48 (Apr. 1, 1997) (acquirer of VC-backed startup insists on 90\% common-shareholder approval to obtain pooling-of-interests accounting treatment for acquisition).
} 
Carrots $\mathcal{E}$ Sticks

Because common shareholders' approval is sometimes needed as a matter of corporate law (in states where approval by each class of stock is required) or business practice, VCs can (and sometimes do) negotiate for "drag-along" rights that allow them to force common shareholders to vote for any transaction favored by the VCs. ${ }^{43}$ If the common shareholders have agreed to vote their shares as directed by the VCs, they cannot block an exit transaction via a class vote. ${ }^{44}$ They must then seek other means to stop the transaction.

\section{Potential Entrepreneurial-Team Resistance to Trade Sales}

This Part explores why the entrepreneurial team may resist a trade sale that the VCs propose. Section A explains why founders and other executives may oppose, and may be able to impede, a trade sale. Section B explains why common shareholders may oppose, and may be able to impede, a trade sale.

\section{A. Resistance by the Founder and Executives}

The founder and other executives may have both reasons and the means to oppose a trade sale.

\section{Incentive}

Consider a founder who is still the CEO. The founder/CEO may have ambitious (perhaps grandiose) financial and non-financial aspirations for the startup. He or she may believe that these aspirations can be realized only if the startup remains independent and he or she remains in control. A trade sale may well snuff out these aspirations (imagine if Facebook had been sold in a trade sale to, say, Google or Microsoft). To the extent the founder/CEO wants to keep the startup independent so that it can realize its full "potential," he or she may oppose a trade sale.

Whether or not the founder is still part of the management team, the firm's executives might have two very practical reasons to oppose a trade sale. First, the executives may well be replaced or subject to tighter supervision as the firm comes under the control of a single shareholder (the acquirer). Executives could thus be forced to give

\footnotetext{
43 See Robert P. Bartlett, III, Venture Capital, Agency Costs, and the False Dichotomy of the Corporation, 54 UCLA L. REV. 37, 62 n.98 (2006)(describing drag-alongs). Depending on its terms, the drag-along may not be effective unless the board has also voted to approve the sale.

${ }^{44}$ To the extent common shareholders have agreed to vote their shares as directed by the VCs, and the shares are voted in favor of a transaction, the common shareholders may lose their right to appraisal, which is generally available only to shareholders who vote against the transaction. See, e.g., 8 DEL.C. § 262(a) (2010). Cf. Corp. Law Comm. of the Assoc. of the Bar of the City of N.Y., The Enforceability and Effectiveness of Typical Shareholders Agreement Provisions, 65 Bus. Law. 1153, 1183-84 (2010) (reporting that, as of 2010, "[n]either New York nor Delaware courts have explicitly ruled whether a waiver of appraisal rights in the context of a drag-along sale is enforceable.").
} 
up the pay, perquisites, and prestige associated with their positions - or to work harder for them. ${ }^{45}$

Second, executives may own substantial amounts of common stock in the firm, especially if they are part of the founding team. As we discuss below, a trade sale may yield little for common shareholders while eliminating the option value of their stock. ${ }^{46}$ To the extent executives own common stock that they will be forced to give up for less than its option value, they have another reason to try to block a trade sale.

\section{Ability}

Executives of VC-backed firms seeking to block a trade sale have three potential means to do so. First, and most importantly, they can refuse to cooperate in the sale of the firm. They can refuse to report acquisition interest to the VCs, they can drag their feet in dealing with a potential acquirer, they can refuse to provide information (and emphasize negative aspects of the business) to a potential acquirer. Moreover, if a potential acquirer wants members of the executive team to stay on after the acquisition (for example, to continue developing a startup's technology), executives can block the deal by refusing to work for the acquirer. In short, executives can use their positional power in the firm to undermine and sabotage efforts to sell it.

Second, to the extent executives have seats on the board, they can threaten to vote against a sale and try to persuade independent directors to oppose the transaction. Attorneys advising a board may prefer a vote to be unanimous because it reduces litigation risk. The desire for a unanimous vote would increase the ability of even a minority of directors to impede a sale.

Third, if common-shareholder approval is necessary for the deal, and executives own a large block of common shares, they can threaten to vote their shares against the deal and lobby other common shareholders to oppose the deal. This brings us to common-shareholder opposition to trade sales.

\section{B. Opposition by Common Shareholders}

Common shareholders, like executives, may also have an incentive (and some ability) to impede a trade sale.

\section{Incentive}

VCs exiting via trade sale always have the ability to retain their preferred shares rather than converting them into common shares. In this scenario, the VCs have

\footnotetext{
${ }^{45}$ Executives of VC-backed startups facing potential trade sales are in the same position as the executives of publicly traded companies facing takeover attempts or merger proposals. See generally Hartzell, Ofek \& Yermack, supra note 19, at 38. Of course, in some cases a trade sale might make the executive team better off. In those cases, executives would not oppose the sale.

${ }^{46}$ See infra Part III.B.1.
} 


\section{Carrots $\mathcal{E}$ Sticks}

liquidation preferences that must be paid in full before common shareholders receive any payout. Thus, common shareholders may not receive much, if anything, in a trade sale. However, even if the VCs' liquidation preferences exceed the sale price, the common stock might have, at the time of sale, considerable "option value:" if the firm is not sold now, it might later hit a home run and be sold later for a price that exceeds the preferred shareholders' liquidation preferences, giving a large payout to common shareholders. ${ }^{47}$ The less common shareholders receive, and the greater the loss of option value, the more common shareholders will wish to block a trade sale.

In blocking a sale, the common shareholders may not be trying to keep the startup independent so that it can go public. Rather, they may resist a trade sale today because they believe that, if the startup remains independent, there is a good chance that it can exit in the future via a more attractive trade sale - one that provides significantly more value for common shareholders.

\section{Ability}

Common shareholders can block a trade sale in three ways: (a) using their shareholder voting rights; (b) litigating or threatening litigation; and (c) using their influence over the board.

\section{(a) Shareholder voting rights}

As we explained in Part II.B.2, common-shareholder approval may be necessary to conduct a trade sale. In particular, such approval will be necessary if (1) commonshareholder approval is required by corporate law and/or the acquirer, and (2) the VCs fail to negotiate effective drag-along rights enabling them to force the common shareholders to vote for a VC-favored sale. If neither corporate law nor the acquirer demands common-shareholder approval, or the VCs have effective drag-along rights, then common shareholders cannot threaten to hold up the deal through their voting rights.

\section{(b) Fiduciary-duty and other litigation}

To try to block a deal, common shareholders can also threaten to sue the board or the VCs directly for, among other things, breach of fiduciary duties under corporate law. Common shareholders' litigation leverage will depend in part on the corporate laws of the state in which the firm is domiciled. The easier it is to demonstrate breach of fiduciary duty under that state's corporate law, the more leverage common shareholders will have.

\footnotetext{
${ }^{47}$ Consider, for example, a startup with $\$ 50$ million in aggregate liquidation preferences. Assume there is a $50 \%$ likelihood that, within one year, the firm will be worth $\$ 90$ million and a $50 \%$ likelihood that it will be worth \$0. A hypothetical risk-neutral buyer content to earn a 0\% return would pay \$45 million for all of the equity of the startup. Preferred shareholders would get $\$ 45$ million; common shareholders would get \$0. But if the startup were to remain independent, the common stock would have an expected value of $\$ 20$ million because there is a 50\% likelihood of a \$90 million sale yielding \$40 million for common stockholders. That $\$ 20$ million is the “option value” of the common stock that is lost in the sale of the firm today for $\$ 45$ million.
} 


\section{Carrots $\mathcal{E}$ Sticks}

But two limits to common shareholders' ability to credibly threaten litigation are worth noting. First, aggrieved common shareholders will often lack the financial ability to sue VCs. ${ }^{48}$ Second, there may well be large reputational costs to litigating against VCs. ${ }^{49}$ All in all, the actual likelihood of litigation is likely to be low.

\section{(c) Board Influence}

A third mechanism by which common shareholders can impede a trade sale is by asking their representatives on the board (if there are any) and any independent directors (if there are any) to vote against the transaction. Common shareholders will have considerable influence on board votes if a majority of the board seats are not held by the VCs, but rather by common-shareholder representatives and/or independent directors. Indeed, given directors' preference for unanimous board votes, even a stubborn minority of directors who care about the interests of common shareholders might be able to block a sale that is unfavorable to common shareholders.

\section{VCs’ Potential Carrots and Sticks}

In Part III, we saw that founders, other executives and common shareholders of VCbacked startups may have the incentive and ability to resist a trade sale. In this Part, we describe the potential carrots and sticks that VCs can use to induce founders and other executives (Section A) and common shareholders (Section B) to go along with trade sales. $^{50}$ Section $\mathrm{C}$ explains that, from the VCs’ perspective, both carrots and sticks entail costs.

\footnotetext{
${ }^{48}$ See Fried \& Ganor, supra note $\mathrm{x}$, at 1000-01. Lawyers will generally not take such cases on a contingency basis because the amounts involved in any given case are likely to be relatively small. The plaintiffs would thus need to finance the potentially extensive litigation themselves. Defendants, whose litigation will be financed by the target's D\&O insurance policies, can be expected to engage in a scorchedearth defense to financially exhaust the common-shareholder plaintiffs. Members of the entrepreneurial team, even collectively, are unlikely to have the substantial resources necessary to finance such litigation.

49 See Fried \& Ganor, supra note $\mathrm{x}$, at 1000-01. The founders and employees holding common stock may wish to raise money from VCs in the future for other ventures, or work at other VC-backed startups. Acquiring a reputation as a "troublemaker" who sues VCs is likely to make it more difficult to raise funds from VCs or to get positions at VC-backed firms in the future. Consider the story of Epinions.com, whose founders, including Naval Ravikant, filed suit against several prominent VC firms for fraud in connection with a 2004 merger that wiped out the value of their common shares. After the merger but before the lawsuit, Ravikant had become a partner at another VC firm, Dot Edu Ventures. Shortly after the lawsuit was filed, Dot Edu Ventures expelled Ravikant under pressure from other VC firms, which may well have threatened to exclude Dot Edu Ventures from deals unless it pushed out Ravikant. According to one person close to the situation: "[Ravikant] had better win this suit and he better hope that he makes enough for life, because he'll never work as a VC again.” See Constance Loizos, VC Gets Frozen Out After Joining Suit, PRIVATE EQUITY WEEK, $\quad$ Feb. http://www.privateequityweek.com/pew/freearticles/1107338724787.html (alteration in original).
}

${ }^{50}$ Because VCs provide financing in stages, and have the ability to prevent the firm from getting debt or equity financing elsewhere, they can always wield an "implicit” stick of starving the company of cash until management and common shareholders agree to sell the company. However, use of such a stick might also reduce the value of the VCs' investment in the firm. In addition, if members of the entrepreneurial team 


\section{A. Founders and Executives}

To induce founders and other executives to facilitate rather than impede a trade sale, VCs may offer carrots or deploy various sticks.

\section{Carrots}

For founders and other executives, the VCs can use direct carrots (management bonuses) or indirect carrots (carve-outs to common shareholders).

\section{(a) Management Bonus}

The direct carrot is a "management bonus" triggered by the sale (and, perhaps, with an amount tied to the sale price). The bonus may be structured in a variety of ways. For example, executives can be promised ex ante (even before an acquirer is identified) a portion of the sale proceeds. Alternatively, executives may be given a contemporaneously negotiated payment labeled as a "bonus" or instead characterized as part of a noncompete agreement or consulting agreement. ${ }^{51}$

The cost to VCs of using a management-bonus carrot will depend on the sale price relative to aggregate liquidation preferences at the time of sale. If the sale price exceeds aggregate liquidation preferences, most or all of the carrot will be paid for by the original common shareholders, not the VCs. ${ }^{52}$ If the sale price is less than aggregate liquidation preferences, the VCs will pay for the carrot.

\section{(b) Carve-out to common}

The indirect carrot is a carve-out to the common shareholders as a class. A carveout entitles common shareholders to a portion of the trade-sale proceeds even if the firm is sold for less than the VCs' liquidation preferences. To the extent the founders and executives own shares of common stock, they will share pro rata in the carve-out. For example, if founders and executives own $50 \%$ of the common stock, a carve-out to common of \$10 million will yield founders and executives \$5 million.

\section{Sticks}

VCs facing recalcitrant founders and other executives have two potential sticks at their disposal.

expect to get little in the sale, the threat of destroying the firm may not induce them to support the sale. For these two reasons, there are limits to the power of this stick.

${ }^{51}$ A retention agreement with the acquiring firm may also function as a carrot if its actual purpose is to overcome the executive's resistance to the sale rather than to increase the value of the acquirer by binding valuable human capital to the acquiring firm.

52 If the VCs have participating preferred stock, they will pay for part of the carrot. If the VCs have nonparticipating convertible preferred stock, the common shareholders will bear all of the cost of the carrot. 


\section{(a) Termination}

First, VCs could threaten to fire the founder and other executives if they refuse to cooperate in a trade sale. Termination would cut off future compensation and perhaps cause the forfeiture of unvested equity. Such a step would be quite painful for the executives.

But such a tactic would also be quite costly to the VCs. The startup would lose its management team, which may be crucial to a potential buyer, the VCs would be forced to spend time and energy finding a replacement, and the new team would then need to be brought up to speed and adequately incentivized to sell the firm. As a result, we would expect this stick to be wielded rarely, if at all.

\section{(b) Blacklisting}

Second, VCs could threaten to "blacklist" founders and other executives who refuse to cooperate in a trade sale. VCs are repeat players in both funding entrepreneurs and hiring professional executives for startups. Neither entrepreneurs nor professional managers will want to displease the VCs, everything else equal.

\section{B. Common Shareholders}

To induce common shareholders to support a trade sale, the VCs have one carrot at their disposal, and a number of sticks.

\section{Carrot: Carve-out to Common}

The carrot VCs can offer common shareholders is a carve-out from their liquidation preferences (or other cash-flow rights) so that common shareholders receive more than they are contractually entitled to receive. Such a carve-out to common can both induce common shareholders to vote for the sale and cause them to refrain from suing.

\section{Sticks}

VCs can wield a number of sticks to compel common shareholders (as a class) to vote for the trade sale. However, these sticks cannot prevent a lawsuit and, in fact, may increase the likelihood of one.

\section{(a) Cross-voting}

To eliminate common shareholders' ability to block a trade sale, VCs can partially convert their shares into common stock, or exercise warrants to buy common stock, thereby acquiring a sufficient amount of common stock to achieve the necessary approval threshold. Consider the transactions in Orban v. Field, ${ }^{53}$ a Delaware case involving a common-shareholder lawsuit against a VC-controlled board. Office Mart, a

53 No. 12820, 1997 Del. Ch. LEXIS 48 (Apr. 1, 1997). 


\section{Carrots $\mathcal{E}$ Sticks}

Delaware corporation, arranged to be acquired by Staples in a merger providing no payout to common shareholders. ${ }^{54}$ The charter allowed preferred shareholders to vote alongside common shareholders on an as-converted basis (as if their stock had been converted into common shares), and the preferred shareholders had enough votes to ensure shareholder approval of the transaction for corporate-law purposes. However, for accounting reasons, Staples insisted that at least $90 \%$ of Office Mart's common shares be voted in favor of the transaction. ${ }^{55}$ Common shareholders, led by Office Mart's founder and former CEO George Orban, refused to back the deal, demanding \$4 million in exchange for their votes. ${ }^{56}$

Office Mart's board refused to provide a carve-out to common. Instead, the board arranged a series of transactions that, in essence, assisted the VCs in converting a portion of their preferred stock into common, thereby diluting the original common position down to less than $10 \%$ of the class. ${ }^{57}$ The VCs, now holding over $90 \%$ of the common stock, voted their common stock in favor of the merger, which allowed the transaction to go forward and wiped out the common shareholders. The maneuver cost the VCs nothing; although the partial conversion into common reduced the VCs' aggregate liquidation preferences, it still left them with enough liquidation preferences to absorb all of the merger consideration. Orban sued, arguing that Office Mart's board had violated its fiduciary duties to common shareholders. The Delaware Chancery ruled in favor of the board, concluding that the "common stockholders had no legal right to a portion of the merger consideration under Delaware law or the corporate charter" 58 and noting that "[t]here is no claim that the challenged transaction was not in the 'best interests of the corporation.,",59

\footnotetext{
54 See id. at *2.

55 Id. at *17.

56 Id. at *22.

${ }^{57} \mathrm{Id}$. at *22-24.

58 Id., at *32. Of course, the issue here was not, as the court implies, how to divide the proceeds of an already-effected merger. In fact, the merger had not yet taken place. Rather, the issue was whether a preferred-controlled board could use corporate resources to dilute the voting power of common shareholders objecting to a proposed merger that benefitted the preferred shareholders and left the common shareholders with nothing.

${ }^{59}$ For an analysis of how Orban can be reconciled with cases finding that boards controlled by common shareholders can advance the interests of the common shareholders at the expense of the preferred shareholders, see Fried and Ganor, supra note x, at 991-93 (suggesting that Delaware courts have adopted a "control-contingent" approach to fiduciary duties in which boards controlled by preferred shareholders can advance the interests of preferred shareholders at the expense of common shareholders as long as the challenged decisions can be defended as in the "best interests of the corporation" and boards controlled by common shareholders can advance the interests of common shareholders at the expense of preferred shareholders as long as the preferred shareholders’ contractual rights are respected).
} 


\section{(b) Vote-buying}

VCs can also overcome common-shareholder opposition by buying the votes of stockholders, such as executives, who already own a large block of common stock. For instance, assume that three executives of a startup collectively hold $55 \%$ of the common stock, and that a trade sale cannot occur without approval by $50 \%$ of the common shareholders. Rather than providing a carve-out to all common stockholders, the VCs could simply award each of these three individuals a lucrative cash bonus or other payment in connection with a trade sale in exchange (implicitly) for voting their common shares in favor of the transaction. Vote-buying via payments to executives can thus kill two birds (executive opposition and common-shareholder opposition to the trade sale) with one stone.

Alternatively, a VC-controlled board can issue additional common shares to certain executives or employees who expect to gain from the board's proposed transaction, and will thus vote these common shares in favor of the transaction. ${ }^{60}$ Although vote-buying in some (or all) of these cases may violate the board's duty to refrain from improperly tampering with the shareholder vote, ${ }^{61}$ it is very difficult to prove that the purpose of a particular payment or equity issuance to executives or employees is to buy votes.

\section{Carrots vs. Sticks}

We have seen that VCs have at their disposal both carrots and sticks to induce entrepreneurial teams to cooperate in trade sales. Carrots tend to involve out-of-pocket costs. For example, carve-outs to common come solely at the VCs' expense. ${ }^{62}$ But many sticks, such as threats to terminate or blacklist a founder or other executives, do not involve any cash outlay. ${ }^{63}$

\footnotetext{
${ }^{60}$ For example, the plaintiffs bringing suit in Kalashian v. Advent VI L.P., No. CV-739278, 1996 WL 33399950 (Cal. App. Dep’t Super. Ct. Oct. 4, 1996) (in re Alantec) alleged (among other things) that the VCs had given common stock to new management solely to undermine the voting power of the original common shareholders and prevent them from blocking an economically dilutive financing. After trial, the VCs ended up settling for \$15 million. See Kenton J. King, Warning: Rescue May Risk Risks, NAT’L L. J., Nov. 24, 1997.

${ }^{61}$ See Portnoy v. Cryo-Cell Int'l, Inc., 940 A.2d 43, 67 (Del. Ch. 2008) (citing Schreiber v. Carney, 447 A.2d 17, 25-26 (Del. Ch. 1982) for the proposition that vote buying, where the purpose is to defraud or in some way disenfranchise other stockholders, is per se illegal).

${ }^{62}$ Management bonuses would come solely at the expense of the VCs if the firm is sold for an amount less than aggregate liquidation preferences. However, if the firm is sold for an amount greater than aggregate liquidation preferences, management bonuses would be subsidized by common shareholders, either partially (if VCs have participating preferred stock) or completely (if VCs have non-participating preferred stock).

${ }^{63}$ Vote-buying and cross-voting might require dipping into the VCs' pockets, but not always. Consider first vote-buying. Vote-buying can be done completely at the expense of common shareholders if value the original common shareholders would otherwise (absent the vote-buying) have received is used to pay for
} 


\section{Carrots $\mathcal{E}$ Sticks}

However, sticks can give rise to substantial indirect costs. First, although litigation is unlikely in any given case, the use of sticks may well increase the risk of litigation, which can be very costly (should it occur) in terms of VCs' time and reputation. ${ }^{64}$ Second, VCs may be deterred from "misbehaving" because of reputational considerations. ${ }^{65}$ As websites like thefunded.com make the world smaller and more transparent, and serial entrepreneurs play a more important role in startups, the reputational costs to VCs who bully entrepreneurial teams with sticks are likely to become higher. Thus, both carrots and sticks can be costly to VCs.

\section{Research Sample}

\section{A. Sample Population}

We study the use of carrots and sticks in trade sales of VC-backed startups using a hand-collected data set of VC-backed Silicon Valley firms. This section describes the data collection process and provides descriptive statistics for the firms in our sample.

\section{Data Gathering}

The data used for this project were collected in 2005-2007 as part of a study supported by the Kaufmann Foundation and UC Berkeley. We obtained from VentureReporter.net a list of VC-financed companies located in California that were sold in trade sales in 2003 or 2004. We filtered out all firms except those located in and around San Francisco, San Jose, and Oakland (broadly defined as "Silicon Valley"), ${ }^{66}$ leaving a population of 193 firms.

the votes. For example, suppose that absent vote-buying, common shareholders as a class would receive $\$ 5 \mathrm{~m}$ in a sale and a majority of the common shareholders would oppose such a sale. The VCs then pay executives a net amount of \$4m to exercise underwater options to acquire (on a post-exercise basis) 50\% of the outstanding common shares and vote their shares in favor of the transaction. Common shareholders as a class now receive $\$ 1 \mathrm{~m}$, with $50 \%$ of that $\$ 1$ million going to the executives.

Next consider cross-voting. Again, cross-voting can often be done at no out-of-pocket cost to VCs. Suppose, for example, that VCs' liquidation preferences are $\$ 50 \mathrm{~m}$ and the sale price is $\$ 40 \mathrm{~m}$. The VCs can convert $20 \%$ of their shares into common stock and vote these common shares without reducing the value of their liquidation preferences and their payout in the sale.

${ }^{64}$ See Vladimir Atanasov, Vladimir Ivanov, \& Kate Litvak, Does Reputation Limit Opportunistic Behavior in the VC Industry? Evidence from Litigation Against VCs, 67 J. FIN. 2215, 2226-27, 2244 (2012).

65 See Black \& Gilson, supra note 8, at 262-63 (arguing that geographical proximity between VCs and investment portfolio companies gives rise to reputational constraints, deterring opportunistic acts by VCs); Sahlman, supra note 3, at 513 (arguing that VCs refrain from abusing their power because they wish to attract the best entrepreneurs who can choose other VCs or alternative sources of capital).

${ }^{66}$ We used LinkSV to filter out firms not meeting these criteria. LINKSV, http://www.linksv.com (last visited Feb. 4, 2013). LinkSV profiles all companies located in Silicon Valley (in or around San Jose, San Francisco, and Oakland) that received VC funding. Companies not appearing on LinkSV were removed from our sample. 


\section{Carrots $\mathcal{E}$ Sticks}

For each firm we sought to locate and obtain data from one or more persons knowledgeable about the firm's life - including the circumstances surrounding its sale. We identified current business addresses for the founders or executives (all of whom we call "entrepreneurs" for convenience) of 141 of the 193 companies. We mailed letters asking entrepreneurs from each firm to provide us with data, promising to keep confidential the identity of the entrepreneur and the startup firm.

Entrepreneurs from 57 of the 141 firms agreed to provide us with data - a response rate of $40.4 \%$. The information obtained, supplemented by publicly filed corporate charters, covered each firm's entire lifespan. Among the data gathered were the state of incorporation, cash-flow rights, and control rights negotiated in each VC financing round; the identities and backgrounds of the CEO and directors; and the circumstances and terms of sale, including amounts paid to various classes of shareholders and managers.

From the original set of 57 firms, we removed seven for lack of adequate data, leaving us with 50 firms. In most of these sales (42 out of 50) the VCs exited as preferred shareholders. In the remaining eight firms, the VCs converted into common stock in connection with the sale, giving up their liquidation preferences.

\section{Selection Issues}

Because our sample is limited to Silicon Valley firms sold in 2003 or 2004, one must be somewhat cautious about extrapolating from our firms to VC-backed firms generally. Silicon Valley is a close-knit community with its own norms and ways of doing business. ${ }^{67}$ Our sample firms were sold several years after the tech bubble collapsed, a period in which VCs lost considerable amounts of money. These losses may have heightened the conflicts between VCs and entrepreneurial teams around exit events. The use of carrots and sticks within our sample firms could thus be a function of the postbubble time period and/or factors unique to Silicon Valley, limiting the generalizability of our results. ${ }^{68}$

67 See, e.g., Mark C. Suchman \& Mia L. Cahill, The Hired Gun as Facilitator: Lawyers and the Suppression of Business Disputes in the Silicon Valley, 21 L. \& SOC. INQUIRY 679 (1996).

${ }^{68}$ In addition, our sample consists only of companies whose entrepreneurs voluntarily responded to our request for information. There could be systematic differences between firms whose entrepreneurs responded to our inquiries and firms whose entrepreneurs did not. While we sought to minimize such biases by soliciting data from every entrepreneur we could locate, and by offering confidentiality, our sample might not even be completely representative of Silicon Valley firms sold in 2003 and 2004. One reason to think our sample might be unrepresentative, for example, is a higher incidence of litigation compared to other firms. Among the 50 sample firms, there were three lawsuits filed by founders against VC investors, a litigation rate of approximately 6\%. (Two of these lawsuits related to the sale of the firm; one did not. For confidentiality reasons, we cannot disclose any more information about these lawsuits). Among the 143 out-of-sample firms, there was only one founder who filed a lawsuit against VC investors, a litigation rate of less than $1 \%$. This suggests that the frequency of sticks outside our sample might be lower than the frequency of sticks in our sample. 


\section{Carrots $\mathcal{E}$ Sticks}

\section{B. Sample Description}

Our sample firms are 'high-tech' businesses, primarily in the biotech, software, telecommunications, and internet sectors (Panel A of Table 1). The concentration of ITrelated businesses is representative of VC-financed firms generally. ${ }^{69}$ At the time of sale, the firms had received an average of $\$ 42$ million in VC funding and had been operating for an average of approximately five years. The mean sale price is \$55 million. Panel B of Table 1 provides information on the amount invested, financing rounds, years of operation, and sale price.

\section{[INSERT TABLE 1 HERE]}

\section{VCs’ Ex Ante Cash and Control Rights}

We now turn to describe, for the firms in our sample, (1) the VCs' cash-flow rights; (2) the entrepreneurial teams' board seats and shareholder-voting rights; and (3) the identities of the CEOs at the time of sale.

\section{VCs' Cash-Flow Rights}

Across all 50 firms, VCs’ aggregate liquidation preferences at the time of sale are, on average, $\$ 47$ million. In the first round of financing, the liquidation preference usually equals the amount invested (a ' $1 \mathrm{x}$ preference'), while the liquidation preference in subsequent rounds is more likely to be a higher multiple (i.e., $2 \mathrm{x}$ or $3 \mathrm{x}$ ) of the amount invested (Panel C). ${ }^{70}$ At sale, aggregate liquidation preferences are on average somewhat greater than the amount invested (Panel B).

When VCs retain their preferred stock rather than converting to common stock, the allocation of the sale proceeds depends on the relationship between liquidation preferences and the sale price. If liquidation preferences exceed the sale price and contractual priority is fully respected, common stockholders get nothing. Liquidation preferences exceed the sale price in 31 of the 42 firms in which VCs exit as preferred shareholders (Panel D). Absent a carrot, common shareholders (as a class) have little incentive to approve a merger when their equity is underwater. In eight firms, it was in VCs' interest to convert to common stock rather than maintain their liquidation preferences, meaning that the sale proceeds were allocated pro rata among all common shareholders (the original common shareholders and the converting VCs).

\footnotetext{
${ }^{69}$ Kaplan \& Strömberg, 2003, supra note x, at 284.

${ }^{70}$ Liquidation preferences from early rounds of financing are sometimes waived or otherwise reduced in a subsequent round of financing (a "recap" financing). A recap financing may occur as part of a voluntary recapitalization of the firm, perhaps to eliminate "debt" overhang from relatively large liquidation preferences, or alternatively, a pay-to-play contractual provision may force a VC to convert to common stock (and thereby give up its preferences) if it fails to participate in a subsequent financing round. In our sample of 50 firms, there were 13 recap financing rounds (Panel C).
} 


\section{Power of the Entrepreneurial Team}

This section describes the extent of the entrepreneurial teams' blocking power their board seats and corporate law rights - in our sample firms. The data are summarized in Table 2.

\section{(a) Board Seats}

Recall that board approval is required for a trade sale. Thus, the entrepreneurial team may be able to impede a sale through its influence on the board. We divide directors into three categories: (1) VC appointed, (2) common-shareholder appointed, and (3) independent (outside). If a particular outside director had been selected exclusively by the VCs (or the common shareholders), we designate this person as a VC (or common shareholder) director, regardless of how contracting documents label the board seat. ${ }^{71}$

Panel A reports the allocation of board seats. At the time of sale, $56.5 \%$ of all directors are appointed by the VCs, and $22.8 \%$ are appointed by common stockholders. Panel B shows that the VCs controlled the board in 29 of the 50 (58\%) firms. In our sample, common stockholders rarely controlled the board at the time of the sale (3 of the 50 firms). However, in 21 of the 50 firms, the combination of independent directors and common stockholders could have blocked a sale.

\section{[ADD TABLE 2 ABOUT HERE].}

\section{(b) Shareholder Rights}

All our companies were incorporated in either California or Delaware at the time of their sales, consistent with findings that most VC-backed firms incorporate either in their home state or in Delaware. ${ }^{72}$ Panel $C$ shows that 35 out of 50 firms were incorporated in Delaware at the time of the sale. As we explain below, California law may give the entrepreneurial team somewhat more power vis-à-vis VCs through both voting rights and the threat of fiduciary litigation.

(1) Voting rights. California and Delaware provide different voting rights for shareholders. In Delaware, sales need only be approved by holders of a majority of the firm's outstanding stock, both preferred and common. We find that, at the time of sale, VCs almost always have sufficient voting power to dictate the outcome of a stockholderwide vote. $^{73}$ California, on the other hand, requires a separate vote for each class of shareholders, including common. Thus, when the VCs remain preferred shareholders,

\footnotetext{
${ }^{71}$ Our "de facto" classification of directors differs from the "formal" classification used by Kaplan \& Strömberg (2003), supra note x, which treats any board seat intended for a director who is not a VC or a representative of common shareholders as held by an outside director. As one of us has explained elsewhere, nominally independent directors may not be truly independent tie-breakers as between the VCs and common shareholders. See Fried \& Ganor, supra note x, at 988-89.

72 See Brian J. Broughman, Jesse M. Fried \& Darian M. Ibrahim, Delaware LaW as LinguA FRANCA: THEORY AND EVIDENCE 25 (2012) (working paper) (available at http://papers.ssrn.com/sol3/papers.cfm?abstract_id=2117967).

${ }^{73}$ Our findings are consistent with those of Kaplan \& Strömberg (2003), supra note x.
} 


\section{Carrots $\mathcal{E}$ Sticks}

common shareholders of California-domiciled firms can more easily impede a sale they oppose.

But it is not that simple. California purports to subject 'quasi-California' corporations (corporations doing business in California but incorporated elsewhere) to the requirement of separate class votes. ${ }^{74}$ While California's legal ability to impose this requirement on firms incorporated elsewhere is contested, many (but not all) Delawareincorporated companies located in California are advised by lawyers to hold separate class votes. In our sample, all but one Delaware-incorporated firm held a separate class vote for the common.

Thus, as a practical matter, California (rather than Delaware) incorporation may not give common shareholders much more power through voting rights. Nevertheless, common shareholders' ability to impede a transaction is still likely to be somewhat greater in a California-incorporated firm, where a separate class vote is indisputably mandatory. ${ }^{75}$

(2) Fiduciary litigation. Delaware law appears to permit a VC-controlled board to make decisions that favor preferred shareholders at the expense of the common shareholders, as long as the decisions can plausibly be defended as in the "best interests of the corporation."76 In contrast, California law generally affords stronger protection to minority shareholders, including common shareholders in firms with VC-controlled boards. ${ }^{77}$ Thus, directors of California-domiciled firms may believe they face greater risk of liability for harming common shareholders. ${ }^{78}$

\footnotetext{
${ }^{74}$ See CAL. CORP CODE $§ 2115$ (b) (West 1990).

${ }^{75}$ As noted earlier, if the common shareholders have subjected themselves to drag-along rights, they cannot use their voting rights to block a sale. Three entrepreneurs in our sample (2 California-domiciled firms, 1 Delaware-domiciled firm) indicated that drag-along rights limited their ability to vote against a trade sale. We have been told by VC lawyers that drag-along rights are now used much more frequently, especially in deals involving East Coast VC firms.
}

76

See Orban, supra note $\mathrm{x}$. One might think that Orban is no longer good law in light of In re Trados Incorporated Shareholder Litigation, 2009 WL 2225958 (Del. Ch. July 24, 2009). In Trados, the plaintiff common shareholders sued the preferred-affiliated directors for breaching their fiduciary duties to common shareholders by selling the company in a transaction that cashed out the preferred shareholders at an amount close to their liquidation preferences and wiped out common shareholders. The court denied defendant's motion to dismiss under Rule 12b-6, citing earlier cases for the general proposition that directors owe fiduciary duties to the common shareholders and concluding that "it is possible that a director could breach her duty by improperly favoring the interests of preferred shareholders over those of the common shareholders." But the court did not overturn or limit Orban. Rather, the court said that it refused to dismiss the case because, at the $12 \mathrm{~b}-6$ motion-to-dismiss stage, there was not yet enough information in the record to determine that the Trados board, like the board in Orban, had acted "both in good faith and reasonably.” As of this writing, the litigation in Trados is continuing. Meanwhile, Orban appears to remain good law.

${ }^{77}$ Cf. Jones v. H. F. Ahmanson \& Co., 460 P.2d 464, 471 (Cal. 1969) (holding that majority shareholders have a fiduciary responsibility to minority shareholders to use their ability to control the corporation in a fair, just, and equitable manner); DiLillo v. Ustman Techs., Inc., No. B148198, 2001 Cal. App. Unpub. LEXIS 1527 (Nov. 19, 2001) (determining that VC was a controlling shareholder and that plaintiff 


\section{Carrots $\mathcal{E}$ Sticks}

\section{Founders' Position in the Firm}

The entrepreneurial team is likely to have a greater incentive to block a trade sale if the founder is still the CEO. First, a founder-CEO is likely to own more common stock than a replacement CEO, and any option value of the common shares will be destroyed if the firm is sold. Second, a founder-CEO may derive greater non-financial benefits from the business, and thus may have additional incentive to keep the firm independent.

The entrepreneurial team may also have greater ability to impede a sale if the founder is still CEO. A founder-CEO is likely to have substantially more common stock than a hired CEO, giving him more shareholder-blocking power. The founder-CEO is also likely to have longer and deeper relationships than a hired CEO with other directors and common shareholders. As a result, the founder-CEO is likely to have influence over directors and other common shareholders, increasing the likelihood that directors will resist the trade sale and further increasing the likelihood that common shareholders will vote against the transaction.

To reduce resistance to a trade sale, a firm's VC investors may use their control over the board of directors to replace the CEO before the planned exit. In our 50-firm sample, 29 of the founders (58\%) were replaced as CEOs before the firm was sold. (However, as we will discuss shortly, none of these replacements appeared to be made to overcome resistance to a trade sale).

\section{Actual Carrots and Sticks in the Sale of VC-Backed Startups}

Part IV described the potential carrots and sticks that could be deployed by VCs to induce entrepreneurial teams to sell the firm. Here, we describe the actual carrots (Section A) and sticks (Section B) used in our sample. We also describe the total cost to the VCs of the carrots provided in connection with trade sales.

\footnotetext{
common shareholders could sue VC directly for breach of fiduciary duty in connection with the sale of the firm's assets).

${ }^{78}$ However, a quirky feature of California corporate law may make it difficult for common shareholders to prevail against VCs on corporate-law claims when the VCs exit via a merger. Under California law, a firm's insiders have been permitted to eliminate personal liability for violations of corporate law by conducting a merger with an unrelated entity; once the firm has merged, shareholders' only remedy for corporate law violations, even for alleged fiduciary violations that occurred prior to merger, is appraisal. See CAL. CoRP. Code $\$ 1312$ (West 2006); Steinberg v. Amplica, Inc., 729 P.2d 683, 693-94 (Cal. 1986). Delaware law, which is generally considered to be more insider-friendly, does not shield insiders in this manner in ordinary mergers. DeL. CodE AnN. tit. $8 \S 262$ (2010) Rabkin v. P.A. Hunt Chemical Corporation, 498 A.2d 1099 (Del. 1985) (holding that courts should examine allegations of "specific acts of fraud, misrepresentation, or other items of misconduct" in connection with a merger even if appraisal is available to plaintiffs as a remedy).Thus, if a California court today were to follow Steinberg, commonshareholder plaintiffs would be worse off, in some respects, than if the firm had been subject to Delaware corporate law.
} 


\section{Carrots $\mathcal{E}$ Sticks}

\section{A. Carrots}

\section{Common Carve-outs}

In our sample, 11 sales ( $22 \%$ of 50 ) feature carve-outs to common shareholders extra value above the amount to which they were contractually entitled. To measure these carve-outs, we compare the actual payout received by VCs to the VCs' contractual entitlement. When the VCs convert to common shares, their contractual entitlement equals their pro rata share of the sale price. When the VCs exit as preferred shareholders, their contractual entitlement is the lesser of their liquidation preferences and the sale price. $^{79}$ Any excess payment received by the original common shareholders is treated as a common carve-out.

Table 3 describes the common carve-outs in our sample. Limited to the 11 sales in which a carve-out occurred, the average carve-out to common stock is $\$ 3.7$ million, or approximately $10 \%$ of the total purchase price. Though most firms do not provide a carve-out, carve-outs can be substantial when they occur. In our sample, one sale provided a \$10 million carve-out to common stockholders, and in two deals the carve-out was at least $25 \%$ of the total purchase price.

Common carve-outs only occurred in the 42 firms where the VCs exit holding preferred stock. Limited to the subsample of 42 firms where VC investors did not convert to common shareholders, we find that common stockholders receive, on average, $\$ 969,000$ more than their contractual entitlement, or approximately $2.5 \%$ of the total purchase price. Among all 50 companies, common stockholders receive, on average, $\$ 810,000$ more than their contractual entitlement, or approximately $2.2 \%$ of the total purchase price.

Carve-outs to common shareholders are illustrated in Figure 1. Each bar represents a firm's total sale price (in millions of dollars). The sale price is divided into four components: (i) the amount actually paid to VCs (in black); (ii) the contractual entitlement of the original common stockholders at the given sale price (in white); (iii) the carve-out given to the original common stockholders (in dark grey); and (iv) nonretention bonuses paid to senior management in connection with the sale (in light grey).

\section{[INSERT FIGURE 1 HERE]}

\section{[ADD TABLE 3 HERE]}

In our sample, common carve-outs are used, at least in part, to overcome common shareholders' opposition to trade sales. We showed econometrically elsewhere that these carve-outs are more likely to occur when: (1) VCs lack de facto board control (and thus need to convince other directors, such as independent directors and common-appointed directors, to support the sale); (2) the firm is domiciled in California, rather than Delaware, and therefore common shareholders' rights are likely to be slightly stronger;

\footnotetext{
${ }^{79}$ The sale price is defined as the amounts paid to VCs and common shareholders. In those cases where (a) the sale price exceeds the liquidation preferences and (b) the VCs exit holding participating preferred stock, we define VCs' cash-flow rights as the sum of the liquidation preferences and the participation rights.
} 


\section{Carrots $\mathcal{E}$ Sticks}

and/or (3) common shareholders would otherwise be wiped out and receive none of the sale proceeds. ${ }^{80}$

Qualitative interview data confirm that carve-outs to common shareholders are designed to induce common shareholders and their allies on the board to support the sale. In one California-domiciled firm, for example, the VCs carving out a portion of their liquidation preferences for common shareholders required each common stockholder to sign a liability waiver before receiving a portion of the carve-out. According to the entrepreneur, the carve-out was offered only because the VCs were concerned about a possible common shareholder suit challenging the terms of sale. In another case, where the VCs lacked board control, the entrepreneur told us that the VCs were forced to give a carve-out payment to common shareholders to obtain the support of other directors.

Of course, some of the carve-outs to common might have had other motives. VCs might have wanted to be "fair" to common shareholders or to build or maintain a reputation as "friendly" VCs. However, the fact that these carve-outs are more likely to occur when common shareholders have more power, or more incentive to block a sale, suggests that they are being used, at least in part, to induce common shareholders' cooperation with sales.

\section{2. (Non-retention) Management Bonuses}

Bonuses that do not require management to stay with the acquirer might be used as carrots to induce executives to support a sale. ${ }^{81}$ Of the 50 firms in our sample, 16 offered various non-retention management bonuses in connection with the acquisition, with an average bonus in these 16 firms of $\$ 1.63$ million (or $6.6 \%$ of the sale price). Bonuses are sometimes given to a broad class of employees (5 firms), but in most cases they are limited to key executives (11 firms).

Among all 50 companies, senior executives receive an average non-retention bonus of approximately $\$ 520,000$. Across all companies, these payments represent approximately $2.1 \%$ of the total purchase price (or $0.95 \%$ on a dollar-weighted basis). ${ }^{82}$ Compared to bonuses awarded in connection with the sale of publicly held firms, the

\footnotetext{
${ }^{80}$ See Broughman \& Fried, Renegotiation, supra note $\mathrm{x}$, at 394.

${ }^{81}$ Retention arrangements (arrangements that require executives to stay with the acquirer) could, in theory, be used either as arm's-length deals by the acquirer to keep target talent or as carrots to induce executives to support the deal. In our sample, 19 founders reported that retention agreements or related compensation arrangements (such as options for the acquirer stock) were negotiated in connection with the sale. Because we were not given any reason to believe that these arrangements were designed to serve as carrots, and because their value is difficult to measure, we report data only on non-retention bonuses.

${ }^{82}$ Most of these payments came at the expense of the VCs. Across the 50 firms in our sample, a total of \$26 million was paid out in the form of non-retention management bonuses. Of this amount, \$22.5 million came at the expense of preferred stockholders, and only \$3.5 million came at the expense of common stockholders.
} 


\section{Carrots $\mathcal{E}$ Sticks}

payments we document are modest in dollar terms, but large as a fraction of deal size. ${ }^{83}$ Non-retention management bonuses are depicted in Figure 1.

Of course, VCs might have other reasons to give executives a management bonus besides inducing them to sell the company. They may want to reward the executives for a job well done, or to curry favor with executives whom they hope to hire in the future. Thus, we cannot be certain that all of the non-retention bonuses observed were salerelated carrots.

\section{Cost of Carrots}

In our sample, 23 of the 50 firms offer a management bonus or common carveout. Limited to the group of 23 firms offering a carrot, Figure 2 illustrates the value of these benefits relative to the sale price. In most cases, total carrots represent between $5 \%$ and $12 \%$ of the sale price, with a mean amount of approximately $\$ 2.9$ million, or $9.4 \%$ of deal value (Table 3). In two firms, however, total carrots exceed $20 \%$ of the total deal value.

Across all 50 firms, the total cost of carrots (those given to executives plus those given to common shareholders) is about $\$ 1.33$ million for the average sample firm (Table 3 ). Across all companies, the average carrot is approximately $4.3 \%$ of the purchase price (or 2.4\% on a dollar-weighted basis). ${ }^{84}$

[INSERT FIGURE 2 HERE]

The use of carrots is greater in the 42 firms in our sample where the VC investors did not convert to common stock, and thus where the conflict between the entrepreneurial team and VCs was likely to be the greatest. In this subsample of 42 firms we find that the total cost of carrots is about $\$ 1.51$ million for the average firm and that approximately $5.0 \%$ of deal value (3.1\% on a dollar-weighted basis) was used to fund carrots.

\section{B. Sticks}

As explained earlier,the two potential sticks available to VCs in dealing with recalcitrant executives are firing them and threatening to blacklist them, and two sticks that can be used against common shareholders are cross-voting and vote-buying. The section below describes the use of such sticks in our sample.

\footnotetext{
${ }^{83}$ See Jay Hartzell, Eli Ofek \& David Yermack, What's in It for Me?: CEOs Whose Firms Are Acquired, 17 REV. FIN. STUD. 37, 43-46 (2004) (finding that CEOs of publicly held target firms, on average, receive a non-retention merger bonus worth approximately $\$ 1.2$ million; which is only about $0.1 \%$ of the average acquisition price [ $\$ 1.2$ billion] of the deals in the Hartzell, Ofek \& Yermack study).

${ }^{84}$ Of the $\$ 1.33$ million average carrot, $\$ 1.26$ million was paid by the preferred shareholders and $\$ 70,000$ was paid by the common shareholders.
} 


\section{Carrots $\mathcal{E}$ Sticks}

\section{Termination of CEO}

Recall that 29 of the 50 founders of our firms had been replaced before the sale. But these replacements typically occurred well before the sale, usually in connection with a later round of financing. ${ }^{85}$ After three years of operation, approximately $30 \%$ of the firms in our sample had replaced the founder-CEO. Of those firms still in operation after six years, approximately $63 \%$ of the firms had replaced the founder-CEO. ${ }^{86}$ Data on the timing of CEO replacement in our sample are summarized in Table 4.

\section{[INSERT TABLE 4 HERE]}

In fact, none of the entrepreneurs providing us with data indicated that any founder (or other executive) was fired or threatened with being fired immediately in connection with a contemplated sale. Moreover, while the impetus for replacing the founder-CEO typically came from the VCs, there was little conflict over the replacement of the founder-CEO. ${ }^{87}$ None of the terminated founder-CEOs reported that the VCs had caused the firm to repurchase vested options, or had fired the founder-CEO to strip him or her of unvested equity, a possibility raised by Michael Klausner and Kate Litvak. ${ }^{88}$

Indeed, most of the replaced founders reported significant involvement with the firm after the CEO change. The founder-CEO remained on the board following the CEO replacement in almost 60\% (17 out of 29) of our sample firms. Even when the founder does not keep a board seat, he or she generally has some position with the firm after replacement (often serving as the Chief Technology Officer or in some other executive capacity).

To be sure, even if we do not observe forcible termination, the possibility of such termination is always present. The possibility of termination limits the value of management bonuses executives can extract from the VCs.

\section{Blacklisting}

In two firms [\#35 and \#50], VCs explicitly threatened to prevent a founder from ever raising money again in Silicon Valley if he or she did not vote (as a director) for the

\footnotetext{
${ }^{85}$ In 3 of the 29 firms where the founder was replaced as CEO, the founder-CEO was replaced in connection with the first round of VC financing (meaning the founder agreed to resign as CEO in exchange for the financing). In the other 26 firms, the founder-CEO was replaced at a later date, typically after several rounds of financing.

${ }^{86}$ Our evidence regarding the timing of CEO replacement is roughly consistent with Michael T. Hannan, M. Diane Burton \& James N. Baron, Inertia and Change in the Early Years: Employment Relations in Young, High-Technology Firms, 5 InDUS. \& CORP. CHANGE 503, 525-26 (1996) (finding that the likelihood that a non-founder will be appointed CEO is about $10 \%$ in the first 20 months of a company's life, $40 \%$ after 40 months, and $80 \%$ after 80 months).

${ }^{87}$ For more background on CEO replacement in startup firms, see discussion in Brian Broughman, Investor Opportunism and Governance, in VENTURE CAPITAL: INVESTMENT STRATEGIES, STRUCTURES, AND PoliCIES (Douglas Cumming ed., 2010) at 355 - 357.

${ }^{88}$ See Klausner \& Litvak, supra note 3, at
} 


\section{Carrots $\mathcal{E}$ Sticks}

sale. In each of these firms, the founder's support was not necessary as a matter of corporate law to conduct the sale - the VCs had control of the board - but the VCs wanted a unanimous board vote to reduce liability risk. And they got it.

Again, the fact that blacklisting was explicitly threatened in only two firms does not mean that founders or executives in other firms were not affected by the possibility of blacklisting. We have been told by venture capitalists and VC lawyers that entrepreneurs are keenly aware, without being explicitly told, that if they behave "unreasonably" toward the VCs backing their firm it will be very difficult for them to raise funds from other VCs in the future. Our results thus understate the importance of blacklisting constraints on the entrepreneurial team.

\section{Cross-Voting}

In one firm [\#29], VC investors engaged in cross-voting (the scheme used in Orban v. Fields). Firm \#29, which was California-domiciled, received \$50 million over 3 rounds of VC financing and was sold in 2004 for $\$ 20$ million. At the time of sale, the VCs already controlled the board of directors, the founder had already been replaced as CEO, and the VCs collectively had liquidation preferences exceeding \$100 million (the third-round financing included a $3 \mathrm{X}$ preference). The founder refused to vote his common stock in favor of the sale. ${ }^{89}$ Because the firm was incorporated in California, approval from a majority of voting common stockholders was necessary to sell the firm, giving the founder some degree of blocking power. To eliminate this holdup, the VCs converted a fraction of their preferred stock into common. This maneuver did not cost the VCs anything because, as in Orban, the VCs were left post-conversion with liquidation preferences far greater than the $\$ 20$ million sale price.

Firm 29 was the only company in our sample where this form of cross-voting was actually used. However, other founders, especially those of firms whose common stock was far underwater, reported that they were aware that VCs could engage in this tactic. Thus, demands for common carve-outs are made in the shadow of possible crossvoting. $^{90}$

\section{Vote-Buying}

Vote-buying reportedly occurred in one firm [\#49] in our sample. The firm was California-domiciled and there were no drag-along rights. The founder reported that the VC-controlled board paid the CEO and other employees to exercise options that were underwater $^{91}$ to acquire and vote common stock in favor of a trade sale for about $\$ 80$

\footnotetext{
${ }^{89}$ The VCs in this firm did not appear to hold drag-along rights that could compel a vote of common stockholders.

${ }^{90}$ The cost to VCs of cross-voting is higher if reduces their aggregate liquidation preferences below the sale price. In such cases, cross-voting would effectively result in a carve-out for the original common stockholders.

${ }^{91}$ An option is considered to be underwater when its exercise price is higher than the value of the underlying stock, and thus not worth exercising.
} 


\section{Carrots $\mathcal{E}$ Sticks}

million. The VCs used, in addition to this stick, a carrot: they also provided a \$4 million common carve-out. The founder sued the VCs, alleging vote-buying and improprieties associated with a pre-sale financing round. The case was settled for an undisclosed amount.

Of course, implicit and essentially undetectable vote-buying might be occurring through management bonuses because of the considerable overlap between shareholders and executives. Thus, we cannot rule out the possibility that vote-buying was occurring in other firms in our sample.

\section{Part VII. Conclusion}

Trade sales by VCs are actually much more common than IPOs and, in aggregate, are likely to be as financially important to VCs as IPOs. However, unlike IPOs, trade sales do not trigger the intense public-disclosure requirements of the securities laws. As a result, we know relatively little about them.

In this paper, we seek to shed light on how VCs arrange to sell startups in trade sales. In particular, we investigate how VCs induce the "entrepreneurial team" - the founder, other executives, and common shareholders - to go along with a trade sale that they might otherwise have an incentive to resist.

We identified the types of bribes (carrots) and coercive tools (sticks) that VCs might use to induce a reluctant entrepreneurial team to support, or at least not impede, a trade sale. We then investigated the use of carrots and sticks using a hand-collected database of 50 VC-backed Silicon Valley firms sold to acquirers in 2003 and 2004. We find, in our sample, a relatively heavy reliance on carrots. Carrots are used in $45 \%$ of the firms, with carrots averaging $9 \%$ of deal value in these firms. We also find some use of sticks, such as threats to blacklist founders who refuse to cooperate and attempts to undermine common shareholders' voting rights. But the overt use of these sticks is relatively infrequent.

Our study makes three contributions. First, it sheds light on an important but underexplored aspect of corporate governance in private VC-backed firms. In particular, it highlights the potentially conflicting interests of different players in VC-backed firms around trade-sale exits, and shows that VCs frequently must overcome potential opposition to these sales by founders, executives, and common shareholders.

Second, our study provides further evidence that managers of target firms can extract value by holding up a sale of the firm. Research has documented the frequent use of side payments to induce executives to participate in the sale of publicly traded firms. We show that such "bribes" are used not only in public firms with dispersed ownership but also in closely held private firms.

Third, our study provides some evidence on whether venture capitalists are constrained from abusing their power in startups. Although venture capitalists have considerable power in startups, the relatively infrequent overt use of sticks in our sample provides support for the view that reputational or other non-legal considerations constrain the misbehavior of Silicon Valley venture capitalists. We hope that our work is useful to 
Version 2/19/13

Carrots $\mathcal{E}$ Sticks

practitioners and academics seeking to better understand the corporate governance of VC-backed firms. 


\section{Carrots $\mathcal{E}$ Sticks}

\section{Table 1: Descriptive Statistics and Liquidation Preferences}

This table provides descriptive statistics for our 50 sample firms. Panel A shows industry distribution. The industry for each company is determined by the sector classification provided by www.linksv.com. Panel $B$ reports the mean and median period of operation, number of financing rounds, amount invested, and sale price. Panel B also shows the aggregate liquidation preferences ("LP") belonging to the VC investors at the time of sale. Panel $\mathrm{C}$ shows the preferences given in each round of financing. The first column lists the number of financing rounds that use $1 \mathrm{x}$ preferences. The second and third columns list financing rounds where preferences between $1 \mathrm{x}$ and $2 \mathrm{x}$, and those greater than $2 \mathrm{x}$, are used. The final column lists financing rounds where the liquidation preferences of earlier investors are waived or reduced (a “recap” financing). Panel D shows, at the time of sale, the number of companies where the LPs are greater or less than the sale price.

\begin{tabular}{l}
$\begin{array}{l}\text { Panel A: Industry Distribution of Companies } \\
\text { Sector } \\
\text { Biotech }\end{array}$ \\
\hline 6
\end{tabular}

\section{Panel B: Financing Overview}

Years of Operation

Number of Financing Rounds

Amount Invested (millions \$)

Sale Price (millions \$)

Aggregate LP (millions \$)

\begin{tabular}{lll} 
Mean & Median & SD \\
\hline 5.1 & 5 & 1.6 \\
3.0 & 3 & 1.1 \\
42.2 & 31 & 36.7 \\
55.0 & 24.3 & 103.9 \\
46.9 & 33.5 & 38.9
\end{tabular}

Panel C: Negotiated Preferences

\begin{tabular}{lllll} 
& $1 \mathrm{x}$ & $\leq 2 \mathrm{x}$ & $>2 \mathrm{x}$ & Recap \\
\hline $1^{\text {st }}$ round $(\mathrm{n}=50)$ & 46 & 2 & 2 & 0 \\
$2^{\text {nd }}$ round $(\mathrm{n}=39)$ & 25 & 10 & 3 & 1 \\
$3^{\text {rd }}$ round $(\mathrm{n}=24)$ & 15 & 2 & 2 & 5 \\
$4^{\text {th }}$ round $(\mathrm{n}=10)$ & 2 & 2 & 2 & 4 \\
$5^{\text {th }}$ round $(\mathrm{n}=5)$ & 1 & 1 & 0 & 3 \\
\hline
\end{tabular}

Panel D: Relation of Liquidation Preferences to Sale price

\begin{tabular}{ll}
$\mathrm{LP}>$ sale price & $\mathrm{LP}<$ sale price \\
\hline 31 & 19
\end{tabular}




\section{Carrots $\mathcal{E}$ Sticks}

\section{Table 2: Control Rights}

This table reports the distribution of corporate governance rights in our sample firms. Panel A reports the mean and median board representation for (1) common shareholders, (2) VCs, and (3) independent (outside) directors. Panel B shows board control at the time of sale. If the VCs (or common) control more than half the board seats, we classify this as "Control." If the board has an even number of seats and the VCs (or common stockholders) appoint exactly half the directors, we treat this as "Blocking." "Shared Control" means that the VCs and the common each appoint fewer than half the directors, with outside directors constituting the tie-breaking vote. Panel C shows the state of incorporation at the time of sale.

\begin{tabular}{llll} 
Panel A: Board Seats at Time of Acquisition & & \\
& & Mean & SD \\
\cline { 2 - 4 } Total number of board seats & 5.74 & 5 & 1.52 \\
Common seats (\% of board) & $22.8 \%$ & $20.0 \%$ & 0.137 \\
VC seats (\% of board) & $56.5 \%$ & $57.1 \%$ & 0.172 \\
Outsider seats (\% of board) & $20.7 \%$ & $20.0 \%$ & 0.185
\end{tabular}

Panel B: Distribution of Board Control

\begin{tabular}{lllll}
$\begin{array}{l}\text { Common } \\
\text { Control }\end{array}$ & $\begin{array}{l}\text { Common } \\
\text { Blocking }\end{array}$ & $\begin{array}{l}\text { Shared } \\
\text { Control }\end{array}$ & $\begin{array}{l}\text { VC } \\
\text { Blocking }\end{array}$ & $\begin{array}{l}\text { VC } \\
\text { Control }\end{array}$ \\
\hline 3 & 0 & 12 & 6 & 29
\end{tabular}

\section{Panel C: State of Incorporation}

State of incorporation at time of sale

\begin{tabular}{lll} 
Delaware & California & Other \\
\hline 35 & 15 & 0
\end{tabular}




\section{Carrots $\mathcal{E}$ Sticks}

\section{Table 3: Carrots}

This table describes common carve-outs and management bonuses in our sample firms. Panel A provides summary statistics for all sample firms. Panel B is limited to those firms that provided a common carveout and/or a management bonus. Data are presented in millions of dollars and as a percentage of the sale price. The included summary statistics are mean, dollar-weighted mean (DW Mean), standard deviation (SD), minimum, and maximum. DW Mean is weighted by the firm's sale price.

\section{Panel A}

\begin{tabular}{lllllll} 
All Companies & \# obs. & Mean & Mean & SD & Min. & Max \\
\hline Common Carve-out (millions \$) & 50 & 0.81 & - & 2.20 & 0 & 10 \\
Management Bonus (millions \$) & 50 & 0.52 & - & 1.17 & 0 & 6 \\
Combined Carrot (millions \$) & 50 & 1.33 & - & 2.63 & 0 & 10.31 \\
Common Carve-out (\% of Sale Price) & 50 & $2.2 \%$ & $1.47 \%$ & .058 & 0 & $26.7 \%$ \\
Management Bonus (\% of Sale Price) & 50 & $2.1 \%$ & $0.95 \%$ & .039 & 0 & $16.7 \%$ \\
Combined Carrot (\% of Sale Price) & 50 & $4.3 \%$ & $2.42 \%$ & .078 & 0 & $43.3 \%$
\end{tabular}

\section{Panel B}

\begin{tabular}{lllllll}
$\begin{array}{l}\text { Companies with Common Carve-out } \\
\text { and/or Management Bonus }\end{array}$ & \# obs. & Mean & $\begin{array}{l}\text { DW } \\
\text { Mean }\end{array}$ & SD & Min. & Max \\
\hline Common Carve-out (millions \$) & 11 & 3.67 & - & 3.18 & .03 & 10 \\
Management Bonus (millions \$) & 16 & 1.63 & - & 1.61 & .1 & 6 \\
Combined Carrot (millions \$) & 23 & 2.89 & - & 3.27 & .03 & 10.31 \\
Common Carve-out (\% of Sale Price) & 11 & $10.1 \%$ & $8.91 \%$ & .088 & $1 \%$ & $26.7 \%$ \\
Management Bonus (\% of Sale Price) & 16 & $6.6 \%$ & $6.19 \%$ & .041 & $1.8 \%$ & $16.7 \%$ \\
Combined Carrot (\% of Sale Price) & 23 & $9.4 \%$ & $9.19 \%$ & .093 & $1 \%$ & $43.3 \%$
\end{tabular}




\section{Carrots $\mathcal{E}$ Sticks}

\section{Table 4: The CEO Position}

Table 4 records the identity of the CEO in our sample firms. The CEO position is held either by a founder or by a replacement, and is recorded as of the end of each year of operation for each firm. Panel B illustrates CEO replacements over time. The horizontal axis represents the lifespan of each firm from formation to sale, normalized to one unit, and the vertical axis shows the percentage of the sample firms that have replaced the CEO at each point.

\section{Panel A}

\begin{tabular}{|l|l|ll|ll|}
\hline Year & Obs. & \multicolumn{2}{|l|}{ Founder CEO } & \multicolumn{2}{l|}{ Replacement CEO } \\
& & $\#$ & $\%$ & & $\#$ \\
\hline 1 & 50 & 47 & $94 \%$ & 3 & $6 \%$ \\
2 & 50 & 42 & $84 \%$ & 8 & $16 \%$ \\
3 & 48 & 34 & $71 \%$ & 14 & $29 \%$ \\
4 & 42 & 26 & $62 \%$ & 16 & $38 \%$ \\
5 & 31 & 13 & $42 \%$ & 18 & $58 \%$ \\
6 & 19 & 7 & $37 \%$ & 12 & $63 \%$ \\
7 & 11 & 3 & $27 \%$ & 8 & $73 \%$ \\
8 & 5 & 2 & $40 \%$ & 3 & $60 \%$ \\
$9+$ & 3 & 1 & $33 \%$ & 2 & $67 \%$ \\
\hline
\end{tabular}

\section{Panel B}

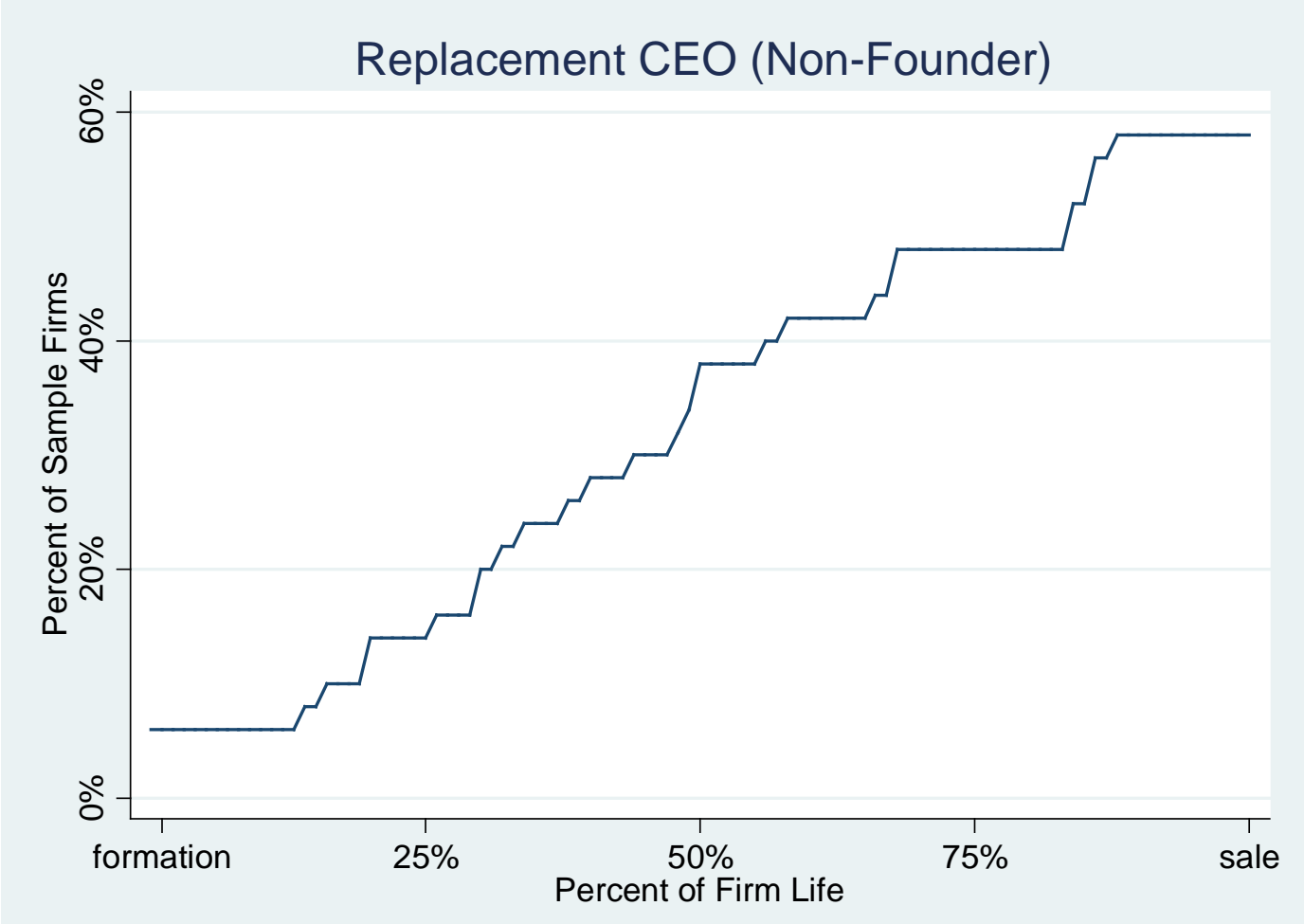




\section{Figure 1}

Using data from our sample firms, this figure shows the distribution of exit proceeds among VCs, common stockholders, and senior management. Each bar represents a firm's total sale price (in millions of dollars). The sale price is divided into four components: (i) the amount actually paid to VCs (in black); (ii) the contractual entitlement of the original common stockholders (in white); (iii) the carve-out given to the original common stockholders (in dark grey), and (iv) non-retention bonuses paid to senior management in connection with the sale (in light grey). For ease of presentation, all firms sold for more than $\$ 100$ million are normalized to a purchase price of \$100 million.

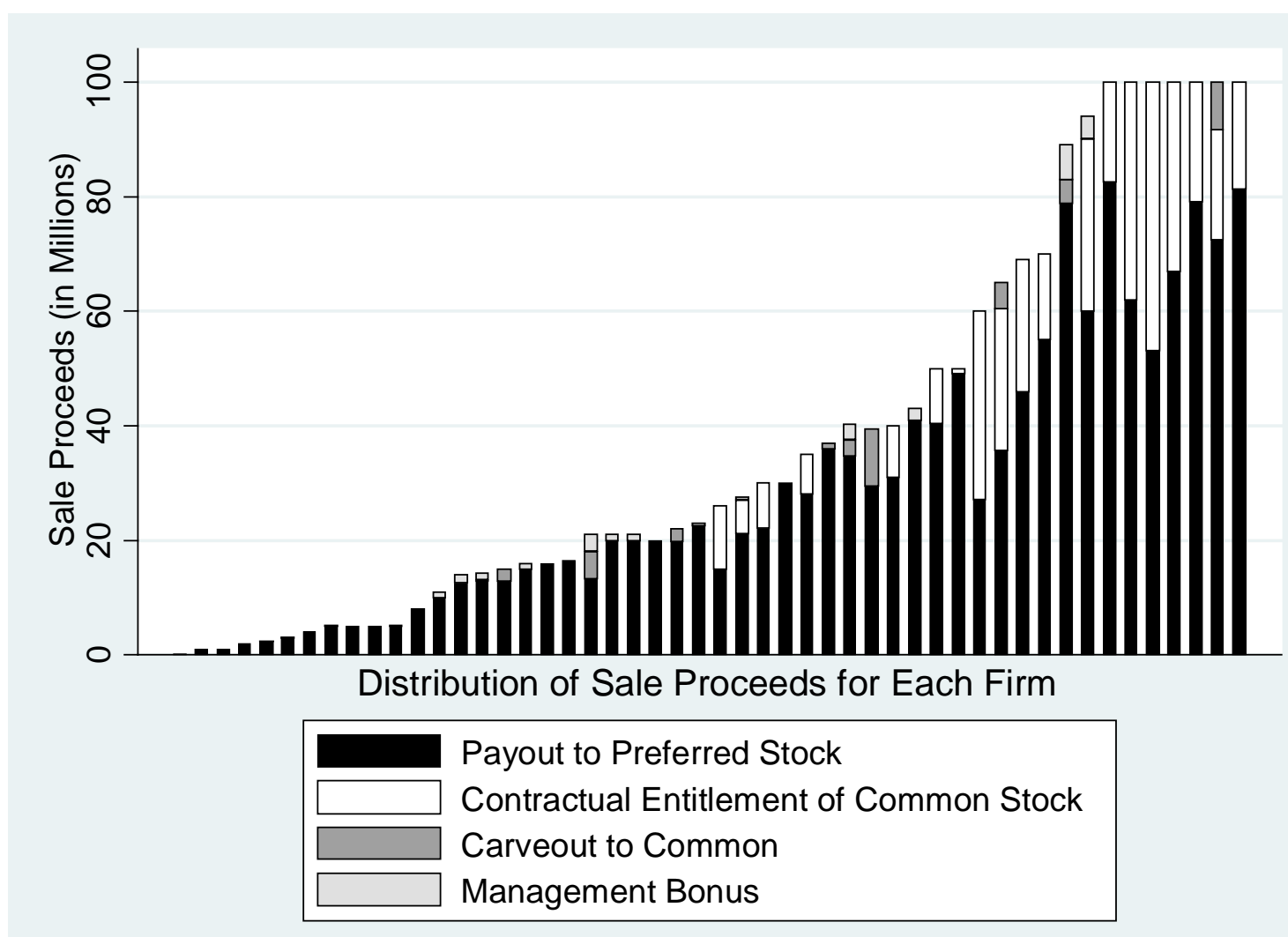




\section{Figure 2}

For each of the 23 firms in our sample that provided a common carve-out or management bonus, Figure 2 shows such payouts as a percentage of the total sale price. Common carve-outs are shown in dark grey and management bonuses in light grey.

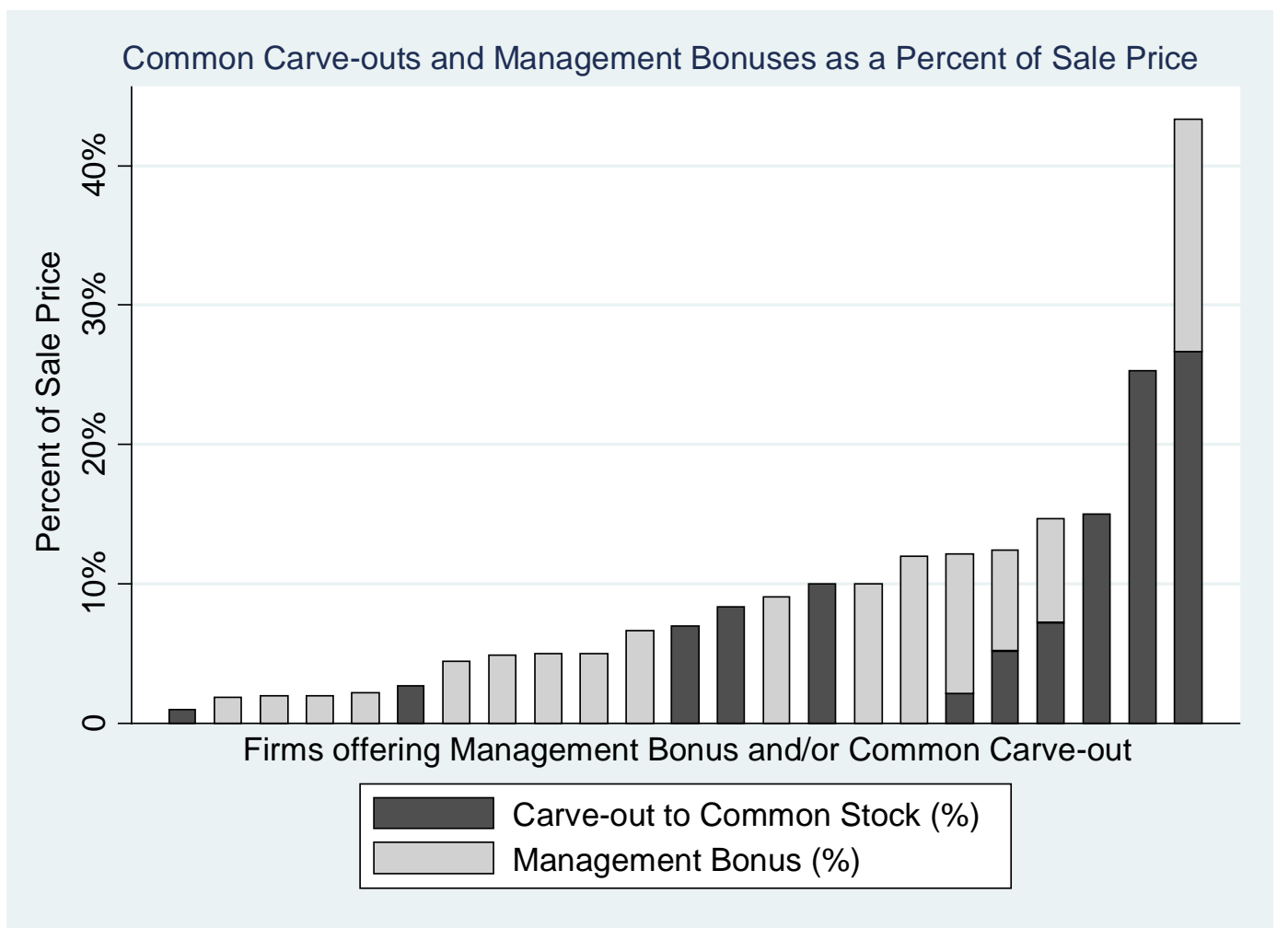

